Janusz Józef WĘC

Uniwersytet Jagielloński

janusz.wec@uj.edu.pl

\title{
DYNAMIKA REFORMY USTROJOWEJ STREFY EURO W LATACH 2012-2016
}

ABSTRACT The Dynamics of the system reform of the Eurozone in the years 2012-2016 The article shows the dynamics of the system reform of the Eurozone in the years 2012-2016. The first part of the article concentrates on the implementation of the system reform in the period since the adoption by the European Council Herman Van Rompuy's report on 13th/14th December 2012 until the creation of organisational foundations for the Banking Union. The second part has been devoted to the work on the reform after publishing on 22 June 2015 what is know as Five President's Report.

Słowa kluczowe: reforma ustrojowa strefy euro, Unia Europejska, traktat lizboński, Rada Europejska, Rada Unii Europejskiej, Komisja Europejska, Parlament Europejski, Unia Bankowa, Unia Gospodarcza, Unia Fiskalna, Unia Finansowa, Unia Polityczna

Keywords: system reform of the euro area, European Union, Lisbon Treaty, European Council, Council of the European Union, European Commission, European Parlament, Banking Union, Economic Union, Fiscal Union, Financial Union, Political Union 


\section{UWAGI WSTĘPNE}

Globalny kryzys finansowy w znacznej mierze przyczynił się nie tylko do wybuchu kryzysu zadłużeniowego niektórych państw członkowskich strefy euro na przełomie 2010/2011 r., lecz także obnażył słabości instytucjonalne i ustrojowe całej strefy ${ }^{1}$. Pierwsze próby reform podjęte w latach 2011-2012 sprowadzały się zasadniczo do wzmocnienia zarządzania gospodarczego i budżetowego w Unii Gospodarczej i Walutowej (UGiW). Polegały one m.in. na wprowadzeniu mechanizmów i procedur nadzoru, przyjęciu kilku nowych aktów prawnych oraz podpisaniu umów międzyrządowych. Nowymi regulacjami były: pakt euro plus $(2011)^{2}$; semestr europejski $(2011)^{3}$; sześciopak, czyli sześć aktów prawnych zwiększających dyscyplinę fiskalną i nadzór makroekonomiczny w UGiW w celu wzmocnienia Paktu stabilności i wzrostu oraz ustanowienia nowych mechanizmów eliminujących zakłócenia równowagi makroekonomicznej (2011); dwupak, czyli dwa akty prawne umożliwiające ustanowienie wspólnego harmonogramu budżetowego dla państw strefy euro (2011); pakt fiskalny jako umowa międzyrządowa zawierająca przepisy służące zwiększeniu dyscypliny budżetowej oraz wzmocnieniu koordynacji polityki gospodarczej państw strefy euro i zarządzania nią (2012), a także traktat ustanawiający Europejski Mechanizm Stabilności (European Stability Mechanism - ESM) jako instytucję wspierającą finansowo państwa strefy euro mające poważne trudności gospodarcze lub zagrożone nimi

Jako początek kryzysu zadłużeniowego Komisja Europejska podaje przełom 2010 i 2011 r. Por. Komisja Europejska, Notatka prasowa. Unia Bankowa: przywracamy stabilność finansowa w strefie euro, Bruksela, 15 IV 2014 r., s. 1. Szerzej na temat przyczyn kryzysu zadłużeniowego strefy euro por. J. Frankel, Causes of Eurozone Crises, [w:] Eurozone Crisis. A Consensus View of the Causes and a Few Possible Solutions, red. R. Baldwin, F. Giavazzi, London 2015, s. 109-120; T. Kunstein, W. Wessels, Die Europäische Union in der Währungskrise. Eckdaten und Schlüsselentscheidungen, „Integration” 2011, Vol. 34, nr 4, s. 308-322, [online] http://dx.doi.org/10.5771/0720-5120-2011-4-308; M. Pietrzykowski, Polska na drodze do reformowanej strefy euro, Poznań 2014, s. 44-58; M. Götz, Kryzys i przysztośćstrefy euro, Warszawa 2012. Por. też M. Gruszczyński, Kryzysy walutowe, bankowe i zadtużeniowe w gospodarce światowej, Warszawa 2013.

2 Pakt euro plus został przyjęty przez Radę Europejską w dniach 24-25 III 2011 r. i zobowiązywał państwa UGiW do koordynacji działań w celu pobudzenia konkurencyjności ich gospodarek, wzrostu zatrudnienia oraz zwiększenia stabilności finansów publicznych i budżetów. Do paktu euro plus przystąpiły wszystkie państwa członkowskie strefy euro oraz sześć państw do niej nienależących - Bułgaria, Dania, Litwa, Łotwa, Polska i Rumunia (stąd nazwa pakt euro plus). Por. J.J.Węc, Pierwsza polska prezydencja w Unii Europejskiej. Uwarunkowania - procesy decyzyjne - osiagnięcia i niepowodzenia, Kraków 2012, s. 132-133, Societas, 44.

3 Semestr europejski był obowiązującą od 1 I 2011 r. procedurą oceny, koordynacji i nadzoru nad politykami gospodarczymi i budżetowymi państw strefy euro, scalającym działania zaplanowane w strategii „Europa 2020” oraz pakcie euro plus. Obejmował on trzy elementy składowe: nadzór makroekonomiczny, koordynację oraz nadzór fiskalny. O ile dwa pierwsze elementy tego mechanizmu dotyczyły krajowych programów reform, o tyle ostatni odnosił się do programów stabilności lub konwergencji, przygotowywanych na mocy Paktu Stabilności i Wzrostu. Por. tamże; Rada Unii Europejskiej. Sekretariat Generalny, Jak wygladda europejski semestr?, s. 1-2, [online] http://www.consilium.europa.eu/pl/ policies/european-semester/, 30 IV 2016. 
$(2012)^{4}$. Ponadto z dniem 1 stycznia 2011 r. rozpoczął działalność Europejski System Nadzoru Finansowego (European System of Financial Supervisions - ESFS) 5 . Wszystkie te inicjatywy nie przyniosły jednak oczekiwanych rezultatów. W 2012 r. kryzys zadłużeniowy nie tylko nadal się utrzymywał, ale także wciąż realna była groźba jego rozprzestrzenienia się z jednych państw członkowskich strefy na drugie. W tej sytuacji zrodził się zamysł przeprowadzenia kompleksowej reformy ustrojowej strefy euro, której realizację rozpoczęto pod koniec $2012 \mathrm{r}$.

W artykule przedstawiono dynamikę reformy ustrowej strefy euro w latach 2012-2016. Pierwsza część pracy poświęcona została procesowi konceptualizacji oraz realizacji reformy w latach 2012-2015, czyli od przyjęcia przez Radę Europejską raportu Hermana Van Rompuya w dniach 13-14 grudnia 2012 r. aż do utworzenia zrębów organizacyjnych Unii Bankowej. W drugiej części zaprezentowano dalsze zmiany ustrojowe, opierające się na tzw. raporcie pięciu przewodniczących z 22 czerwca 2015 r., a także ich realizację w okresie od 1 lipca 2015 r. do połowy 2016 r.

4 Europejski Mechanizm Stabilności uzyskał zdolność operacyjną 8 X 2012 r. i miał charakter stałego mechanizmu kryzysowego dla państw strefy euro. W 2013 r. zastąpił on dwa inne podmioty udzielające tymczasowo (w pierwszej fazie kryzysu) pomocy finansowej państwom dotkniętym kryzysem zadłużeniowym, czyli Europejski Mechanizm Stabilizacji Finansowej (European Financial Stabilisation Mechanism - EFSM) oraz Europejski Instrument Stabilności Finansowej (European Financial Stability Facility - EFSF). Szerzej na temat wszystkich wspomnianych reform realizowanych w latach 2011-2012 por. J.J.Węc, Pierwsza polska prezydencja..., s. 132-151.

5 Europejski System Nadzoru Finansowego składał się z Europejskiej Rady ds. Ryzyka Systemowego (European Systemic Risk Bard - ESRB) z siedzibą we Frankfurcie nad Menem oraz trzech zorganizowanych sektorowo europejskich urzędów nadzoru: Europejskiego Urzędu Nadzoru Bankowego (European Banking Authority - EBA) z siedzibą w Londynie, Europejskiego Urzędu Nadzoru Giełd i Papierów Wartościowych (European Securities and Markets Authority - ESMA) z siedzibą w Paryżu oraz Europejkkiego Urzędu Nadzoru Ubezpieczeń i Pracowniczych Programów Emerytalnych (European Insurance and Occupational Pensions Authority - EIOPA) z siedzibą we Frankfurcie nad Menem. W skład Europejskiego System Nadzoru Finansowego weszły także Wspólny Komitet Europejskich Urzędów Nadzoru oraz krajowe organy nadzorcze. Europejski System Nadzoru Finansowego był odpowiedzialny za koordynację działań krajowych organów regulacyjnych, spójne stosowanie unijnych przepisów dotyczących sektora finansowego w celu zachowania stabilności finansowej, a także ochronę interesów konsumentów usług finansowych. Europejska Rada ds. Ryzyka Systemowego była niezależnym organem Unii Europejskiej. Sprawowała ona nadzór makroostrożnościowy nad systemem finansowym Unii. Do jej podstawowych zadań należało przeciwdziałanie ryzykom systemowym lub ograniczanie ryzyk systemowych dla stabilności finansowej Unii wynikających z powiązań między instytucjami finansowymi i rynkami czy też z uwarunkowań makroekonomicznych i strukturalnych. Wydawała ona także ostrzeżenia dotyczące zidentyfikowanych ryzyk systemowych oraz zalecenia w sprawie podjęcia niezbędnych działań zaradczych przez właściwe organy państw członkowskich. ESRB ściśle współpracowała z EBC, który zapewniał jej nie tylko sekretariat, ale także wsparcie analityczne, statystyczne, logistyczne i administracyjne. Szerzej na ten temat por. tamże, s. 136-137. 


\section{PIERWSZA FAZA REFORMY W LATACH 2012-2015}

\section{II.1. Projektowane zmiany ustrojowe}

Ramy programowe pierwszej fazy reformy ustrojowej strefy euro określone zostały w dokumentach instytucji Unii Europejskiej, w szczególności Rady Europejskiej, Komisji Europejskiej i Europejskiego Banku Centralnego (EBC). W czerwcu, październiku i grudniu tegoż roku przewodniczący Rady Europejskiej Van Rompuy przedłożył trzy raporty na temat reformy, opracowane we współpracy z przewodniczącym Komisji Europejskiej José Manuelem Barroso, przewodniczącym Eurogrupy Jeanem-Claudem Junckerem oraz prezesem Europejskiego Banku Centralnego Mario Draghim 6 . Własne plany działania w tej sprawie opublikowały również Europejski Bank Centralny (6 września 2012 r.) oraz Komisja Europejska (28 listopada 2012 r.) ${ }^{7}$.

W dniach 13-14 grudnia 2012 r. Rada Europejska zaakceptowała trzeci raport Van Rompuya jako podstawę dalszych prac zmierzających do zakończenia procesu konstytuowania Unii Gospodarczej i Walutowej. W przyjętych wówczas konkluzjach Rada Europejska określiła najważniejsze cele oraz zakres proponowanych zmian ustrojowych w strefie euro. Zmiany te miały być sposobem na przezwyciężenie kryzysu zadłużeniowego ${ }^{8}$.

Trzeci raport Van Rompuya oraz plan działania Komisji Europejskiej zakładały ustanowienie trzech nowych struktur w Unii Gospodarczej i Walutowej: zintegrowanych ram finansowych; zintegrowanych ram budżetowych oraz zintegrowanych ram polityk gospodarczych państw członkowskich strefy euro. Pod pojęciem zintegrowanych ram finansowych kryła się Unia Finansowa, zintegrowane ramy budżetowe oznaczały Unię Fiskalną, zaś przez zintegrowane ramy polityk gospodarczych należało rozumieć Unię Gospodarczą. Utworzenie tych nowych struktur oznaczało poważne ograniczenie suwerenności państw członkowskich strefy euro. Dlatego też Van Rompuy zaproponował również w swoim raporcie ustanowienie bliżej nieokreślonego

6 Rada Europejska, Sprawozdanie przewodniczacego Rady Europejskiej Hermana Van Rompuya „W kierunku faktycznej Unii Gospodarczej i Walutowej”. Komunikat prasowy, Bruksela, 26 VI 2012 r., EUCO 120/12, s. 3; Rada Europejska. Przewodniczący, W kierunku faktycznej Unii Gospodarczej i Walutowej. Sprawozdanie okresowe, Bruksela, 12 X 2012 r., s. 1-8; Rada Europejska. Przewodniczący, W kierunku faktycznej Unii Gospodarczej i Walutowej. [Sprawozdanie końcowe], Bruksela, 5 XII 2012 r., s. 1-18.

7 Komisja Europejska, Komunikat prasowy. Plan dziatania na rzecz pogtębionej i rzeczywistej Unii Gospodarczej i Walutowej (UGW): początek europejskiej debaty, Bruksela, 28 XI 2012 r., IP/12/1272, s. 1-3. Program EBC przewidywał m.in. możliwość dokonywania przezeń nielimitowanego skupu (bez limitu czasu oraz skali operacji) obligacji skarbowych państw strefy euro. Szerszą analizę trzech raportów Van Rompuya, planu działania Komisji Europejskiej oraz programu EBC por. J.J.Węc, The European Union Debate on the Second Institutional Reform (2011-2012), „Przegląd Zachodni” 2014, nr 1, s. 22, 25-29.

8 Posiedzenie Rady Europejskiej w dniach 13-14 grudnia 2012 r. Konkluzje, Bruksela, 14 XII 2012 r., EUCO 205/12, s. 1-5. 
mechanizmu legitymizacji i rozliczalności. Pod tym enigmatycznym pojęciem krył się zamiar rozszerzenia kompetencji instytucji Unii Europejskiej, przede wszystkim Parlamentu Europejskiego, oraz parlamentów narodowych w strefie euro zgodnie $\mathrm{z}$ art. 13 paktu fiskalnego oraz protokołem $\mathrm{nr} 1 \mathrm{w}$ sprawie roli parlamentów narodowych w Unii Europejskiej, załączonym do TUE, TFUE i TEWEA.

Przyjęcie za podstawę programową reformy ustrojowej strefy euro raportu Van Rompuya oraz planu działania Komisji Europejskiej oznaczało także rezygnację z rozważanego w latach 2011-2012 w niektórych państwach członkowskich zamysłu przekształcenia Unii Europejskiej w Unię Polityczną jako sposobu na przezwyciężenie kryzysu zadłużeniowego. Z taką propozycją wystąpili jako pierwsi już w październiku $2011 \mathrm{r}$. przedstawiciele rządu RFN, doprowadzając do publicznej debaty na ten temat zarówno w Niemczech, jak i w Unii Europejskiej'. Jednym z jej przejawów był raport Grupy Refleksyjnej ds. Przyszłości Unii Europejskiej z 17 września 2012 r., opracowany przez ministrów spraw zagranicznych jedenastu państw członkowskich Unii Europejskiej: RFN, Francji, Belgii, Holandii, Luksemburga, Polski, Austrii, Danii, Włoch, Hiszpanii i Portugalii. Raport nie tylko zawierał propozycje zmian ustrojowych w strefie euro, ale także przewidywał kompleksową reformę ustrojową całej Unii Europejskiej, skutkującą przekształceniem tej organizacji międzynarodowej w Unię Polityczną ${ }^{10}$.

Reforma ustrojowa strefy euro przewidywana w trzecim raporcie Van Rompuya oraz planie działania Komisji Europejskiej miała przebiegać w trzech etapach. Pierwszy z nich winien obejmować lata 2012-2013, drugi - lata 2013-2014, zaś etap trzeci miałby się rozpocząć po 2014 r. i stanowić punkt kulminacyjny procesu zmian. Pierwszym krokiem w kierunku utworzenia Unii Finansowej powinno być powołanie do życia Unii Bankowej. Winna się ona opierać na trzech filarach: jednolitym mechanizmie nadzorczym; jednolitym mechanizmie restrukturyzacji i uporządkowanej likwidacji, a także harmonizacji krajowych systemów gwarantowania depozytów ${ }^{11}$. Unia Fiskalna miała powstawać w kilku fazach. Najpierw należałoby zakończyć proces implementacji sześciopaku, paktu fiskalnego i dwupaku, których celem była koordynacja ex ante rocznych budżetów państw członkowskich strefy euro. Następnie powinno dojść do uzgodnienia pułapu rocznego salda budżetowego i długu publicznego dla państw strefy euro, co stworzyłoby uwarunkowania do emisji wspólnego długu bez odwoływania się do uwspólnotowienia długu państwowego. Emisja długu publicznego ponad wspólnie ustalony pułap musiałaby być uzasadniona i uprzednio zatwierdzona przez

9 Szerzej na ten temat por. J.J.Węc, Die politische Debatte zur zweiten Systemreform der Europäischen Union in Deutschland (2011-2012), „Zeitschrift des Verbandes Polnischer Germanisten” 2014, nr 2, s. 201-208.

10 Szerzej na ten temat por. tenże, The European Union Debate..., s. 18-21.

11 Harmonizacja krajowych systemów gwarantowania depozytów miała prowadzić do tego, że $w$ każdym państwie cztonkowskim utworzone zostana wystarczajaco solidne krajowe systemy ubezpieczenia depozytów, co pozwoli na ograniczenie efektów rozlania związanych z ucieczka depozytów do innych instytucji i krajów oraz zapewnienie odpowiedniego stopnia ochrony deponentów w Unii Europejskiej - Rada Europejska. Przewodniczący, W kierunku faktycznej Unii Gospodarczej i Walutowej. [Sprawozdanie końcowe], s. 8 . 
instytucje Unii Europejskiej. Natomiast w perspektywie długoterminowej należałoby ustanowić odrębny budżet strefy euro, nazywany przez Van Rompuya enigmatycznie mechanizmem zdolności fiskalnej (fiscal capacity), a także organ skarbowy o wyraźnie $z$ definiowanych obowiazkach ${ }^{12}$. Unia Gospodarcza winna stanowić dopełnienie Unii Finansowej i Unii Fiskalnej. W perspektywie krótkoterminowej trzeba byłoby zakończyć proces tworzenia jednolitego rynku. Opierając się na semestrze europejskim i pakcie euro plus, należałoby poprawić skuteczność koordynowania głównych reform polityki gospodarczej. W związku z tym powinno dojść do ustanowienia mechanizmu koordynacji ex ante głównych reform polityki gospodarczej zgodnie $\mathrm{z}$ art. 11 paktu fiskalnego, a także mechanizmu koordynacji i konwergencji oraz realizacji polityk strukturalnych służących promowaniu wzrostu i zatrudnienia zgodnie ze strategią „Europa 2020”13. W ramach tego ostatniego mechanizmu zainteresowane państwa członkowskie strefy euro zawierałyby z instytucjami unijnymi umowy reformatorskie, w których zobowiązywałyby się do wzmocnienia konkurencyjności swoich gospodarek, przyspieszenia wzrostu gospodarczego oraz obniżenia bezrobocia. W zamian otrzymywałyby wsparcie finansowe z budżetu Unii Europejskiej ${ }^{14}$.

\section{II.2. Realizacja zmian ustrojowych}

\section{II.2.1. Osiągnięcia}

Proces realizacji postanowień raportu Van Rompuya objął w pierwszej kolejności działania na rzecz ukonstytuowania Unii Bankowej jako części składowej przyszłej Unii Finansowej. Podczas posiedzeń Rady Europejskiej w marcu i czerwcu 2013 r. uzgodniono, że priorytetem $\mathrm{w}$ dalszych pracach będzie właśnie zakończenie procesu ustawodawczego nad Unią Bankową, ponieważ miało to podstawowe znaczenie dla zapewnienia stabilności finansowej państw członkowskich strefy euro ${ }^{15}$. Mimo to proces ten

12 Odrębny budżet strefy euro miałby zabezpieczać państwa do niej należące przed skutkami tzw. wstrząsów asymetrycznych. Por. tamże, s. 8-12, por. też Komisja Europejska. Dyrekcja Generalna Sprawy Gospodarcze i Finansowe, Przysztość UGW. Plan dziatania na przysztość, s. 1, [online] http://ec.europa.eu/economy_finance/explained/economic_and_monetary_union/the_future_of_emu, 30 IV 2016.

13 Rada Europejska. Przewodniczący, W kierunku faktycznej Unii Gospodarczej i Walutowej. [Sprawozdanie końcowe], s. 13.

14 Tamże, s. 14-16.

15 Posiedzenie Rady Europejskiej $w$ dniach 14-15 marca 2013 r. Konkluzje, Bruksela, 14 III 2013 r., EUCO 23/13, s. 9; Posiedzenie Rady Europejskiej w dniach 27-28 czerwca 2013 r. Konkluzje, Bruksela, 28 VI 2013 r., EUCO 104/2/13, REV 2, s. 9-10. Z kolei podczas posiedzenia w marcu 2014 r. Rada Europejska wezwała Parlament Europejski i Radę Unii Europejskiej do jak najszybszego uchwalenia rozporządzenia w sprawie ustanowienia Jednolitego Mechanizmu Restrukturyzacji i Uporządkowanej Likwidacji, a także zaapelowała do rządów państw członkowskich strefy euro o zakończenie negocjacji nad umową międzyrządową w sprawie utworzenia Jednolitego Funduszu Restrukturyzacji i Uporządkowanej Likwidacji. Por. Posiedzenie Rady Europejskiej w dniach 20-21 marca 2014 r. Konkluzje, Bruksela, 21 III 2014 r., EUCO 7/1/14, REV 1, s. 2. 
przebiegał z opóźnieniem. Jednolity Mechanizm Nadzorczy (Single Supervisory Mechanism - SSM), czyli pierwszy filar Unii Bankowej, powstał 4 listopada 2014 r., a nie jak planowano 1 stycznia tegoż roku (trzeci raport Van Rompuya). Utworzenie Jednolitego Mechanizmu Restrukturyzacji i Uporządkowanej Likwidacji (Single Resolution Mechanism - SRM) nastąpiło 1 stycznia 2015 r. Z kolei Jednolity Fundusz ds. Restrukturyzacji i Uporządkowanej Likwidacji (Single Resolution Fund - SRF) uzyskał zdolność operacyjną 1 stycznia 2016 r. ${ }^{16}$ Przyjęto również przepisy legitymizujące wspomniane zmiany ustrojowe w postaci rozszerzenia kompetencji Europejskiego Banku Centralnego, Parlamentu Europejskiego, Komisji Europejskiej, Trybunału Obrachunkowego, Rady Unii Europejskiej i parlamentów narodowych w strefie euro ${ }^{17}$.

Unia Bankowa winna sprawować nadzór nad instytucjami kredytowymi, w tym bankami, strefy euro, ale z drugiej strony ma także gwarantować, że instytucje te będą mogły być likwidowane w sposób kontrolowany, bez szkód dla systemu finansowego państw oraz kosztów, jakie do tej pory ponosili z tego tytułu podatnicy. Podstawę prawną Unii Bankowej stanowią przepisy prawa pierwotnego i pochodnego Unii Europejskiej. W dziedzinie prawa pierwotnego są to postanowienia traktatu o funkcjonowaniu Unii Europejskiej (TFUE), w szczególności art. 114 ust. 1-10, art. 127 ust. 6 oraz art. 53 ust. 1 TFUE $^{18}$.

Jak wspomniano wyżej, Unia Bankowa ma strukturę trzyfilarową, choć nie dysponuje jeszcze pełną strukturą organizacyjną. Pierwszy filar to Jednolity Mechanizm Nadzorczy. Drugi filar stanowią Jednolity Mechanizm Restrukturyzacji i Uporządkowanej Likwidacji oraz Jednolity Fundusz Restrukturyzacji i Uporządkowanej Likwidacji. Natomiast trzecim filarem winna być w przyszłości harmonizacja krajowych systemów gwarantowania depozytów ${ }^{19}$.

16 Warunkiem utworzenia SRF była ratyfikacja umowy międzyrządowej o przekazywaniu i uwspólnianiu składek na jego rzecz, podpisanej 21 V 2014 r. przez 26 państw członkowskich Unii Europejskiej (bez Wielkiej Brytanii i Szwecji). Aby umowa mogła wejść w życie, winny ją ratyfikować państwa reprezentujące co najmniej $90 \%$ łącznej wagi głosów wszystkich krajów uczestniczących w SSM i SMR. Por. J.J.Węc, Proces konstytuowania Unii Bankowej. Geneza, podstawy prawne, cele i zasady dziatania, „Rocznik Integracji Europejskiej” 2014, nr 8, s. 37, [online] http://dx.doi.org/10.14746/rie.2014.8.3. Do 30 XI 2015 r. umowa została ratyfikowana przez 18 spośród 19 państw należących do Unii Bankowej. 29 XII 2015 r. ratyfikowały ją Węgry, jako pierwszy z krajów nieuczestniczących w Unii Bankowej, zaś 11 I 2016 r. Luksemburg, jako ostatnie państwo należące do Unii Bankowej. Polska podpisała tę umowę, ale dotąd jej nie ratyfikowała. Por. Komisja Europejska - drugi filar Unii Bankowej w petni operacyjny, „Przegląd Spraw Europejskich” 2016, nr 1, s. 4.

17 J.J.Węc, Proces konstytuowania Unii Bankowej..., s. 40-42.

18 Traktat z Lizbony zmieniający Traktat o Unii Europejskiej i Traktat ustanawiajacy Wspólnotę Europejska, podpisany w Lizbonie 13 grudnia 2007 r. (teksty skonsolidowane), Dz.U. UE C, 2008, nr 115, s. 90, 124, 134-135. Szersze omówienie tej kwestii, w tym także aktów prawa pochodnego, na mocy których doszło do ustanowienia dotychczasowych struktur Unii Bankowej, por. J.J. Węc, Proces konstytuowania Unii Bankowej..., s. 35-37.

19 J. Koleśnik, Europejska unia bankowa - nowy wymiar ryzyka systemowego, „Problemy Zarządzania” 2013, t. 11, nr 2, s. 101-103; A. Jurkowska-Zeidler, Fundamentalne zmiany regulacji i nadzoru jednolitego rynku finansowego Unii Europejskiej w ramach Unii Bankowej, „Gdańskie Studia Prawnicze” 2015, t. 33, s. 189-192. Niektórzy autorzy błędnie podają, że trzecim filarem Unii Bankowej miał być 
Pierwszy filar Unii Bankowej, czyli Jednolity Mechanizm Nadzorczy, składa się z Europejskiego Banku Centralnego oraz właściwych krajowych organów nadzorczych. Europejski Bank Centralny sprawuje bezpośredni nadzór nad 120 największymi bankami strefy euro, co stanowi ok. $82 \%$ aktywów bankowych w strefie euro ${ }^{20}$. Nadzór ten jest sprawowany przez wspólne zespoły złożone z pracowników EBC i krajowych organów nadzorczych (Joint Supervisory Team - JST). Pozostałe 3500 banków podlega natomiast nadzorowi krajowych organów nadzorczych, ale ostateczną odpowiedzialność za nie ponosi Europejski Bank Centralny. Jego uprawnienia w tym zakresie polegają na wydawaniu i cofaniu zezwoleń na prowadzenie działalności, a także na ocenie nabycia i zbycia znacznych pakietów akcji tychże banków ${ }^{21}$.

Drugi filar Unii Bankowej, czyli Jednolity Mechanizm Restrukturyzacji i Uporządkowanej Likwidacji, zwany także mechanizmem upadłościowym, ma na celu zagwarantowanie, aby w przyszłości potencjalne bankructwa instytucji kredytowych w strefie euro, w tym banków, skutkowały jedynie minimalnymi kosztami dla podatników. Realizację jednolitych zasad i jednolitej procedury upadłościowej zapewnia Jednolita Rada ds. Restrukturyzacji i Uporządkowanej Likwidacji wraz z Radą Unii Europejskiej, Komisją Europejską oraz krajowymi organami ds. restrukturyzacji i uporządkowanej likwidacji. Jednolity Mechanizm Restrukturyzacji i Uporządkowanej Likwidacji może być wykorzystywany jedynie w państwach objętych Jednolitym Mechanizmem Nadzorczym. W pozostałych państwach członkowskich Unii Europejskiej będą podejmowane działania w oparciu o krajowe organy restrukturyzacji i uporządkowanej likwidacji ${ }^{22}$. Jednolity Fundusz Restrukturyzacji i Uporządkowanej Likwidacji, zwany także funduszem upadłościowym, ma być budowany stopniowo przez osiem lat, licząc od 1 stycznia

„europejski system gwarantowania depozytów”, co sugerowałoby, że chodzi o ponadnarodowy system gwarancji, por. M. Zaleska, Unia bankowa - koncepcja i wyzwania, [w:] Unia bankowa, red. taż, Warszawa 2013, s. 16; K. Waliszewski, Koncepcja unii bankowej - szanse i zagrożenia dla sektora banków komercyjnych w Polsce, [w:] Unia bankowa, s. 35; K. Zielińska, Drogi do unii bankowej - reformy systemu regulacji systemu bankowego, „Ekonomia Międzynarodowa” 2013, z. 4, s. 35; G. Nosiadek, Unia bankowa krajów Unii Europejskiej, „Myśl Ekonomiczna i Polityczna” 2014, nr 3, s. 145, 158. Błąd wziął się prawdopodobnie stąd, że pierwszy raport Van Rompuya z czerwca 2012 r. przewidywał ustanowienie „europejskiego systemu gwarantowania depozytów”, ale w kolejnych jego edycjach z października 2012 r. oraz grudnia tegoż roku propozycja ta zniknęła, co wskazywało na to, że brak było wówczas woli politycznej do ustanowienia takiego systemu. Por. Rada Europejska, Sprawozdanieprzewodniczacego Rady Europejskiej Hermana Van Rompuya..., s. 5.

20 Europejski Bank Centralny - rozpoczęcie nadzorowania banków strefy euro przez EBC, „Przegląd Spraw Europejskich" 2014, nr 11, s. 15. Początkowo zakładano, że będzie to 128 banków reprezentujących 85\% aktywów bankowych strefy euro. Por. J.J. Węc, Proces konstytuowania Unii Bankowej..., s. 38.

21 Rozporządzenie Rady (UE) nr 1024/2013 z dnia 15 października 2013 r.powierzajace Europejskiemu Bankowi Centralnemu szczególne zadania w odniesieniu do polityki zwiazanej z nadzorem ostrożnościowym nad instytucjami kredytowymi, Dz.U. UE L, 2013, nr 287, s. 63-89; Europejski Bank Centralny rozpoczęcie nadzorowania banków..., s. 15.

22 Rozporządzenie Parlamentu Europejskiego i Rady (UE) nr 806/2014 z dnia 15 lipca 2014 r. ustanawiajace jednolite zasady i jednolita procedurę restrukturyzacji i uporzadkowanej likwidacji instytucji kredytowych i niektórych firm inwestycyjnych w ramach jednolitego mechanizmu restrukturyzacji i uporzadkowanej likwidacji oraz jednolitego funduszu restrukturyzacji i uporzadkowanej likwidacji oraz zmieniajace rozporzadzenie (UE) nr 1093/2010, Dz.U. UE L, 2014, nr 225, s. 1-90. 
2016 r. W okresie przejściowym, wynoszącym osiem lat od momentu wejścia w życie rozporządzenia, funkcjonował będzie system dualny, złożony z krajowych subfunduszy oraz części wspólnej SRF. Zgodnie z umową międzyrządową z 21 maja 2014 r. składki do Jednolitego Funduszu Restrukturyzacji i Uporządkowanej Likwidacji będą pobierane od banków przez krajowe organy ds. restrukturyzacji i uporządkowanej likwidacji, a następnie przekazywane do tegoż Funduszu. Początkowo środki finansowe będą gromadzone w kopertach (tzw. pulach) przypisanych do poszczególnych państw i winny być przeznaczone wyłącznie na ratowanie banków mających siedzibę w danym państwie. Jednak w ciągu ośmiu lat ulegną one uwspólnotowieniu i wtedy będą mogły być przeznaczone na restrukturyzację dowolnego banku strefy euro. W pierwszym roku uwspólnotowione zostanie $40 \%$ zgromadzonych środków, w drugim roku - kolejne $20 \%$, a reszta - stopniowo przez sześć kolejnych lat. Składki poszczególnych banków do Jednolitego Funduszu Restrukturyzacji i Uporządkowanej Likwidacji będą obliczane proporcjonalnie do kwoty ich zobowiązań oraz stopnia ryzyka ${ }^{23}$. Po upływie okresu przejściowego SFR winien dysponować co najmniej $1 \%$ kwoty depozytów gwarantowanych wszystkich instytucji kredytowych mających swoją siedzibę w państwach uczestniczących w Unii Bankowej. Według danych z $2011 \mathrm{r}$. stanowiłoby to kwotę ok. 55 mld euro ${ }^{24}$.

Istotą trzeciego filaru Unii Bankowej, znajdującego się in statu nascendi, winna być harmonizacja krajowych systemów gwarantowania depozytów, spełniających warunki określone w art. 4 ust. 1 dyrektywy DGSD ${ }^{25}$. Oznacza to, że odpowiedzialność za gwarantowanie depozytów w strefie euro spoczywać ma nadal na władzach krajowych, choć nadzór i decyzja o upadłości danego banku należeć winny do Europejskiego Banku Centralnego. Podstawowym zadaniem trzeciego filaru powinna być ochrona deponentów przed skutkami niewypłacalności instytucji kredytowych. Państwa uczestniczące w Unii Bankowej winny gwarantować tymże deponentom wypłacalność depozytów do 100 tys. euro. W razie zagrożenia upadkiem banki byłyby wprawdzie zmuszone do ochrony swoich depozytariuszy, ale z drugiej strony miałyby także możliwość korzystania z części środków, objętych wspomnianymi gwarancjami, na finansowanie działań pozwalających uniknąc ich upadku ${ }^{26}$. W związku z tym w literaturze słusznie zwraca się uwagę, że ta część przepisów dyrektywy stanowi silny impuls zachęcajacy banki do podjęcia większego ryzyka inwestycyjnego ${ }^{27}$.

23 Umowa o przekazywaniu i uwspólnianiu sktadek na rzecz Jednolitego Funduszu Restrukturyzacji i Uporzadkowanej Likwidacji, Bruksela, 21 V 2014 r., EU/SRF, s. 22-23, 27.

24 Rozporzadzenie Parlamentu Europejskiego i Rady (UE) nr 806/2014z dnia 15 lipca 2014 r. ustanawiajace jednolite zasady..., s. 77.

25 Zgodnie z art. 4 ust. 1 dyrektywy każde państwo cztonkowskie zapewnia utworzenie i urzędowe uznanie na swoim terytorium jednego lub więcej systemów gwarancji depozytów. Nie wyklucza to możliwości potaczenia systemów gwarancji depozytów różnych państw cztonkowskich ani ustanawiania transgranicznych systemów gwarancji depozytów. Zatwierdzenie takich transgranicznych lub potaczonych systemów gwarancji depozytów uzyskuje się od państw cztonkowskich, w których zostaty ustanowione dane systemy gwarancji depozytów - Dyrektywa Parlamentu Europejskiego i Rady 2014/49/UE z dnia 16 kwietnia 2014 r. w sprawie systemów gwarancji depozytów, Dz.U. UE L, 2014, nr 173, s. 158.

26 Tamże, s. 150, 160-163.

27 K. Zielińska, Drogi do unii bankowej..., s. 35. 
W przypadku upadłości banków Jednolity Mechanizm Restrukturyzacji i Uporządkowanej Likwidacji oraz Jednolity Fundusz Restrukturyzacji i Uporządkowanej Likwidacji miały funkcjonować w ścisłym związku z dyrektywą DGSD. Zgodnie z art. 15 ust. 1-4 rozporządzenia z 15 lipca 2014 r. w sprawie ustanowienia Jednolitego Mechanizmu Restrukturyzacji i Uporządkowanej Likwidacji oraz Jednolitego Funduszu Restrukturyzacji i Uporządkowanej Likwidacji za błędy spowodowane przez banki odpowiadaliby w pierwszej kolejności ich akcjonariusze oraz wierzyciele, następnie posiadacze depozytów powyżej 100 tys. euro, a dopiero w ostatniej kolejności (w przypadku braku wystarczających środków) Jednolity Fundusz Restrukturyzacji i Uporządkowanej Likwidacji ${ }^{28}$.

\section{II.2.2. Niepowodzenia}

W toku dotychczasowego procesu konstytuowania Unii Bankowej nie udało się utworzyć Wspólnego Mechanizmu Ochronnego (Common Backstop - CB), co wymagałoby podpisania przez każde państwo należące do Unii Bankowej porozumienia o uruchomieniu linii kredytowej (Loan Facility Agreement) dla SRF. Do 11 maja 2016 r. takie porozumienie podpisało jedynie osiem spośród 19 państw obligatoryjnie uczestniczących w SSM i SRM ${ }^{29}$. Ponadto kilka państw członkowskich Unii Europejskiej nadal nie implementowało do swojego prawa krajowego dwóch istotnych dla Unii Bankowej aktów ustawodawczych: dyrektywy Parlamentu Europejskiego i Rady Unii Europejskiej z 15 maja 2014 r., ustanawiającej ramowe uwarunkowania dla działań naprawczych oraz restrukturyzacji i uporządkowanej likwidacji instytucji kredytowych, a także firm inwestycyjnych (tzw. dyrektywa BRRD) ${ }^{30}$; oraz dyrektywy Parlamentu Europejskiego i Rady Unii Europejskiej z 16 kwietnia 2014 r. w sprawie systemów gwarantowania depozytów (Deposit Insurance Scheme - DIS) (tzw. dyrektywa DGSD) ${ }^{31}$. Obydwie dyrektywy

28 Rozporzadzenie Parlamentu Europejskiejgo i Rady (UE) nr 806/2014 z dnia 15 lipca 2014 r. ustanawiajace jednolite zasady..., s. 39-40.

29 Rada Unii Europejskiej - Posiedzenie Rady Ecofin 25 maja 2016 r. Postepy we wdrażaniu Unii Banko$w e j$, „Przegląd Spraw Europejskich” 2016, nr 5, s. 13.

30 Dyrektywa Parlamentu Europejskiego i Rady 2014/59/UE z dnia 15 maja 2014 r. ustanawiajacca ramy na potrzeby prowadzenia dziatań naprawczych oraz restrukturyzacji i uporzadkowanej likwidacji $w$ odniesieniu do instytucji kredytowych i firm inwestycyjnych oraz zmieniajaca dyrektywe Rady 82/891/EWG i dyrektywy Parlamentu Europejskiego i Rady 2001/24/WE, 2002/47/WE, 2004/25/WE, 2005/56/ WE, 2007/36/WE, 2011/35/UE, 2012/30/UE i 2013/36/EU oraz rozporzadzenia Parlamentu Europejskiego i Rady (UE) nr 1093/2010 i (UE) nr 648/2012, Dz.U. UE L, 2014, nr 173, s. 190-348.

31 Dyrektywa Parlamentu Europejskiego i Rady 2014/49/UE z dnia 16 kwietnia 2014 r. w sprawie systemów..., s. 149-178. Według niektórych autorów Unia Bankowa miała się opierać na następujących trzech filarach: jednolitym mechanizmie nadzorczym; jednolitym mechanizmie restrukturyzacji i uporządkowanej likwidacji, a także powiązanych ze sobą mechanizmach finansowania (wspólnych dla całego rynku wewnętrznego), czyli jednolitym funduszu restrukturyzacji i uporządkowanej likwidacji, systemie gwarantowania depozytów oraz wspólnym mechanizmie ochronnym (linia kredytowa). Oznaczało to, że SRF miałby wchodzić w skład trzeciego filaru. Na przykład zdaniem Justyny Patynowskiej trzeci filar Unii Bankowej opierał się na powiazanych mechanizmach finansowania, $w$ tym na jednolitym funduszu restrukturyzacji i porządkowanej likwidacji banków, systemach gwarantowania 
powinny być implementowane w każdym państwie członkowskim Unii Europejskiej. Termin implementacji dyrektywy BRRD do prawa krajowego upłynął 31 grudnia 2014 r., zaś dyrektywy DGSD - 3 lipca 2015 r..$^{32}$ Do 11 maja 2016 r. nadal nie uczynity tego trzy spośród 28 państw członkowskich Unii Europejskiej33. Brak trzeciego filaru Unii Bankowej oznaczał, że nie dysponowała ona nadal pełną strukturą organizacyjną. W literaturze podkreśla się, że fakt ten uniemożliwiał państwom członkowskim osiągnięcie zakładanych korzyści z Unii Bankowej ${ }^{34}$.

Również dynamika prac nad pozostałymi zmianami ustrojowymi przebiegała z opóźnieniem w stosunku do harmonogramu przyjętego przez Radę Europejską w grudniu 2012 r. W toku były bowiem nadal prace nad utworzeniem Unii Fiskalnej. Weszły wprawdzie w życie sześciopak (grudzień 2011 r.), dwupak (maj 2013 r.) oraz pakt fiskalny (styczeń 2013 r.), jednak wskutek sprzeciwu niektórych państw członkowskich nie rozpoczęto prac nad wspólnym budżetem strefy euro ani nawet nie podjęto decyzji o jego ustanowieniu, czyli najbardziej kontrowersyjnego celu całej reformy. Nie udało się również utworzyć mechanizmu koordynacji i konwergencji oraz realizacji polityk strukturalnych państw strefy euro w oparciu o umowy reformatorskie.

\section{DRUGA FAZA REFORMY OD 1 LIPCA 2015 R.}

\section{III.1. Projektowane zmiany ustrojowe}

Mimo istotnych postępów w procesie tworzenia rzeczywistej Unii Gospodarczej i Walutowej, w szczególności w zakresie konstytuowania Unii Bankowej, trzy spośród czterech celów reformy ustrojowej strefy euro do połowy 2015 r. nadal nie zostały zrealizowane. Ponadto w dalszym ciągu utrzymywały się takie symptomy kryzysu, jak chociażby znaczna rozbieżność w zakresie wyników gospodarczych w całej strefie euro, prawie 18-milionowe bezrobocie oraz zagrożenie wykluczeniem społecznym w wielu państwach członkowskich. W związku z tym nowy przewodniczący Komisji Europejskiej, Jean-Claude Juncker, przedstawił dwa bardzo istotne dokumenty, których

depozytów i wspólnym mechanizmie ochronnym (linia kredytowa) - J. Patynowska, Horyzonty Bankowości 2015: Trzy filary stabilności, „Miesięcznik Finansowy Bank” III 2015, s. 48-50. Por. też J.J. Węc, Proces konstytuowania Unii Bankowej..., s. 3. Zaliczenie SRF do trzeciego filaru Unii Bankowej wzięło się stąd, że w pierwszym raporcie Van Rompuya z czerwca 2012 r. wspomniane wyżej mechanizmy finansowe były łączone razem. Por. Rada Europejska, Sprawozdanie przewodniczacego Rady Europejskiej Hermana Van Rompuya..., s. 5.

32 Przepisy dotyczące bail-in zawarte w dyrektywie BRRD należało natomiast implementować do 31 XII 2015 r. Por. Rada Unii Europejskiej - wdrażanie Unii Bankowej, „Przegląd Spraw Europejskich” 2016, nr 2, s. 10-11.

33 Rada Unii Europejskiej - Posiedzenie Rady Ecofin..., s. 13.

34 K. Waliszewski, Unia bankowa i unia rynków kapitatowych - analiza porównawcza europejskich projektów integracyjnych w obszarze finansowym, „Nauki o Finansach. Financial Sciences” 2015, nr 2, s. 100-101, [online] http://dx.doi.org/10.15611/nof.2015.2.07; D. Schoenmaker, Banking Union: Where We're Going Wrong, [w:] Banking Union for Europe. Risks and Challenges, red. T. Beck, London 2012. 
realizacja miała przyspieszyć prace nad reformą ustrojową strefy euro. 12 lutego $2015 \mathrm{r}$. przedstawił on notę analityczną Przygotowania do kolejnych dziatań $w$ zakresie lepszego zarządzania gospodarczego w strefie euro, zaś 22 czerwca tegoż roku zaprezentował raport Dokończenie budowy europejskiej Unii Gospodarczej i Walutowej. Obydwa dokumenty były przygotowane w ścisłej współpracy z nowym przewodniczącym tzw. szczytu państw strefy euro Donaldem Tuskiem, nowym przewodniczącym Eurogrupy Jeroenem Dijsselbloemem, prezesem Europejskiego Banku Centralnego Mario Draghim, oraz przewodniczącym Parlamentu Europejskiego Martinem Schulzem ${ }^{35}$.

Raport czterech przewodniczących i prezesa EBC, dla uproszczenia zwany odtąd także raportem pięciu przewodniczących, opierał się zarówno na założeniach i celach sprawozdania Van Rompuya z grudnia 2012 r., jak i na komunikacie Komisji Europejskiej z 28 listopada tegoż roku. O ile jednak w dotychczasowym harmonogramie reformy ustrojowej strefy euro, przyjętym na mocy decyzji Rady Europejskiej, które zapadały kolejno w grudniu 2012 r. oraz marcu i czerwcu 2013 r., priorytetem było ustanowienie Unii Bankowej, o tyle w analizowanym raporcie punkt ciężkości spoczywał na mechanizmie koordynacji i konwergencji ex ante polityk gospodarczych państw strefy euro. Było to następstwem decyzji szczytu państw strefy euro z 24 października 2014 r., podczas którego wskazano na priorytetowe znaczenie ściślejszej koordynacji polityk gospodarczych dla zapewnienia sprawnego funkcjonowania Unii Gospodarczej i Walutowej ${ }^{36}$.

Autorzy raportu stwierdzali, że proces pogłębiania Unii Gospodarczej i Walutowej jest otwarty dla wszystkich państw członkowskich Unii Europejskiej. Winien on być przejrzysty i musi chronić integralność jednolitego rynku we wszystkich jego aspektach. Wskazywali również, że mimo niezaprzeczalnych osiągnięć prace nad utworzeniem jednolitego rynku europejskiego nie zostały jeszcze zakończone. Dotyczyło to zarówno liberalizacji przepływu towarów, jak też przepływu usług i kapitału. W związku z tym dokończenie budowy jednolitego rynku towarów i ustug, rynku cyfrowego, rynku energii i rynku kapitatowego i petne wykorzystywanie tych rynków powinno wręcz stanowić element dziatań wspierających tworzenie unii gospodarczej, przyczyniajac siejednocześnie do (powstania) nowych miejsc pracy i wyższego wzrostu gospodarczego ${ }^{37}$.

W raporcie podkreślono, że mimo najgorszego w ciągu ostatnich 70 lat kryzysu finansowego i gospodarczego euro pozostawało nadal drugą co do znaczenia walutą

35 Komisja Europejska, Dokończenie budowy europejskiej Unii Gospodarczej i Walutowej. Sprawozdanie opracowane przez: Jeana-Claudéa Junckera w ścistej wspótpracy z Donaldem Tuskiem, Jeroenem Dijsselbloemem, Mario Draghim i Martinem Schulzem, Bruksela, 22 VI 2015 r., s. 2; Komisja Europejska, Komunikat prasowy. W sprawozdaniu czterech przewodniczacych i prezesa EBC określono plan wzmocnienia europejskiej unii gospodarczej i walutowej od 1 lipca 2015 r., Bruksela, 22 VI 2015 r., s. 1-4.

3624 X 2014 r. podczas szczytu państw strefy euro wydano oświadczenie, $w$ którym podkreślono znaczenie ściślejszej koordynacji polityk gospodarczych państw członkowskich dla sprawnego funkcjonowania UGiW. W ślad za tym przywódcy państw strefy euro zwrócili do przewodniczącego Komisji Europejskiej, aby - we współpracy z przewodniczącym szczytu strefy euro, przewodniczącym Eurogrupy i prezesem EBC - przygotował on raport na temat podjęcia następnych kroków w celu usprawnienia zarządzania gospodarczego w strefie euro. Por. Rada Europejska - oświadczenie przywódców państw strefy euro, „Przegląd Spraw Europejskich” 2014, nr 10, s. 11.

37 Komisja Europejska, Dokończenie budowy europejskiej Unii Gospodarczej i Walutowej..., s. 2. 
na świecie, na którą przypadała prawie jedna czwarta światowych rezerw walutowych, zaś blisko 60 państw i terytoriów zależnych związało z euro kursy swoich walut w sposób bezpośredni lub pośredni. Dzięki dotychczasowej reformie ustrojowej integralność strefy euro jako całości została zachowana, a rynek wewnętrzny utrzymał swoją siłę ${ }^{38}$. $\mathrm{Z}$ drugiej strony w strefie euro istniały nadal znaczne różnice w rozwoju gospodarczym i społecznym, prowadzące do niestabilności w całej Unii Europejskiej. Należało je zatem zniwelować przez realizację czterech następujących celów: po pierwsze, utworzenie rzeczywistej Unii Gospodarczej, dzięki której każda gospodarka będzie miata cechy strukturalne dające jej możliwość pomyślnego rozwoju w ramach Unii Walutowej; po drugie, ustanowienie Unii Finansowej poprzez zakończenie procesu konstytuowania Unii Bankowej oraz przyspieszenie prac nad Unią Rynków Kapitałowych; po trzecie, powołanie do życia Unii Fiskalnej, zapewniającej zarówno długookresową stabilność budżetową, jak i fiskalny mechanizm stabilizacyjny; po czwarte, podjęcie działań zmierzających w kierunku unii politycznej, która winna stanowić podstawę ogółu powyższych przedsięwzięć dzięki prawdziwej demokratycznej odpowiedzialności i zasadności oraz wzmocnieniu instytucjonalnemu ${ }^{39}$.

Autorzy raportu zgodnie podkreślali, że wszystkie cztery unie sq od siebie wzajemnie zależne. Dlatego też winny się one rozwijać równolegle, a wszystkie państwa cztonkowskie strefy euro muszq uczestniczyć $w$ każdej z wyżej wspomnianych unii ${ }^{40}$. Decyzję o ustanowieniu Unii Gospodarczej i Walutowej na mocy traktatu z Maastricht z 7 lutego 1992 r., opierającej się jedynie na wspólnej walucie, ale nieposiadającej nawet zrębów unii gospodarczej, uznawali oni za błędną zarówno pod względem politycznym, jak i ekonomicznym. Porównywali ją do domu, który [...] wykończono tylko częściowo, ale kiedy nadciagnęta burza, konieczne byto szybkie ustabilizowanie jego ścian i dach $u^{41}$.

38 Tamże, s. 4. Niezbędna stała się zatem kontynuacja rozpoczętej w 2012 r. reformy ustrojowej. Zdaniem autorów analizowanego raportu państwa członkowskie strefy euro winny być w stanie lepiej zapobiegać kryzysom poprzez zrównoważoną politykę fiskalną i gospodarczą. Powinny także umieć skutecznie reagować na wstrząsy gospodarcze i absorbować je dzięki wystarczajaco odpornym gospodarkom i odpowiednim buforom budżetowym zdolnym pokryć nieprzewidziane zdarzenia fiskalne w każdej fazie cyklu koniunkturalnego. Gdy bowiem polityka walutowa jest jednolicie ustalana dla całej strefy euro, krajowe polityki budżetowe mają kluczowe znaczenie dla stabilizacji gospodarki po wystąpieniu lokalnego wstrząsu. Gdy wszystkie państwa stosuja jeden kurs wymiany, potrzebują elastycznych gospodarek, które mogtyby szybko reagować na pogorszenie się koniunktury. W przeciwnym razie zaistniałoby ryzyko, że recesja pozostawi gtębokie i trwate ślady. Aby wszystkie gospodarki mogły odnosić trwałe korzyści $\mathrm{z}$ uczestnictwa w strefie euro, winny być również $w$ stanie rozpraszać skutki wstrzasów poprzez podziat ryzyka w ramach Unii Gospodarczej i Walutowej. W perspektywie krótkoterminowej taki podział ryzyka można by osiagnać za pomoca zintegrowanych rynków finansowych i kapitatowych (udziat sektora prywatnego w podziale ryzyka) w potaczeniu z niezbędnymi wspólnymi mechanizmami ochronnymi zwiąanymi z unią bankowa, tj. ostateczną siecia bezpieczeństwa finansowego. W perspektywie średnioterminowej należałoby natomiast wprowadzić mechanizm stabilizacji fiskalnej dla strefy euro jako catości, który będzie zapewniat jej dodatkowa ochronę z tytutu udziatu sektora publicznego w podziale ryzyka (tamize).

39 Tamże, s. 5.

40 Tamże, s. 5-6.

41 Tamże, s. 4 . 
Raport pięciu przewodniczących zawierał właśnie plan zakończenia procesu konstytuowania Unii Gospodarczej i Walutowej w trzech etapach. Etap pierwszy miał obejmować okres od 1 lipca 2015 r. do 30 czerwca 2017 r. W ciągu tych dwóch lat należałoby wykorzystać istniejące instrumenty i traktaty do zwiększenia konkurencyjności i konwergencji strukturalnej, prowadzić odpowiedzialną politykę budżetową na poziomie krajowym i strefy euro, a także wzmocnić legitymację demokratyczną realizowanych reform. W drugim etapie należałoby przeprowadzić bardziej zasadnicze reformy. Winno dojść wówczas m.in. do ustanowienia zestawu wspólnie uzgodnionych wskaźników dotyczacych konwergencji, który miatby charakter prawny, a także do powołania do życia organu skarbowego strefy euro. Natomiast trzeci etap reformy winien doprowadzić do ostatecznego utworzenia w 2025 r. rzeczywistej Unii Gospodaczej i Walutowej ${ }^{42}$.

Autorzy raportu nie precyzowali, kiedy dokładnie miałby się zakończyć drugi etap, a kiedy winien się zacząć trzeci etap reformy ustrojowej ${ }^{43}$. Z drugiej strony zapowiedziano opublikowanie wiosną 2017 r. przez Komisję Europejską Białej Księgi zawierającej szczegółowy harmonogram przejścia od pierwszego do drugiego etapu. W dokumencie tym Komisja Europejska miała także dokonać oceny dotychczasowych prac oraz wskazać na niezbędne dalsze działania, $w$ tym środki o charakterze prawnym, niezbędne do zrealizowania w drugim etapie. Biała Księga winna być opracowana w porozumieniu z przewodniczącymi innych instytucji Unii Europejskiej ${ }^{44}$.

\section{III.1.1. Unia Gospodarcza}

Pakt euro plus nie przyniósł oczekiwanych rezultatów ze względu na swój międzyrządowy i niewiążący prawnie charakter. Ponadto jedną ze słabości tego porozumienia był brak instytucji odpowiedzialnej za monitorowanie stosowania jego postanowień. W związku z tym autorzy raportu zalecali utworzenie rzeczywistej Unii Gospodarczej opartej na konwergencji, wzroście gospodarczym i zatrudnieniu. W tym celu w ramach pierwszego etapu reformy należałoby podjąć cztery działania. Były to: po pierwsze, utworzenie systemu organów ds. konkurencyjności, obejmującego całą strefę euro; po drugie, usprawnienie i wzmocnienie procedury dotyczącej zakłóceń równowagi makroekonomicznej; po trzecie, zwiększenie nacisku na zatrudnienie i kwestie socjalne, m.in. w ramach semestru europejskiego; po czwarte, dalsze usprawnienie i uproszczenie semestru europejskiego, m.in. przez lepsze powiązanie ze sobą kwestii istotnych z punktu widzenia całej strefy euro z problemami poszczególnych państw członkowskich. Wszystkie te działania winny być realizowane zgodnie z metodą wspólnotową, a ich efekty powinny znaleźć odzwierciedlenie w prawie Unii Europejskiej. Natomiast

42 Tamże, s. 2.

43 Najwyraźniej z powodu urzędowej ostrożności, podyktowanej niedotrzymaniem dotychczasowych terminów prac nad reformą strefy euro, w analizowanym dokumencie mówiono już tylko bardzo ogólnie o drugim etapie, w perspektywie średniookresowej i długookresowej, oraz o trzecim etapie jako etapie końcowym, który winien się zakończyć najpóźniej w 2025 r. Por. tamże, s. 22-23 (Zatącznik nr 1: Plan dziatania majacy na celu osiagnięcie petnej Unii Gospodarczej i Walutowej). 
$\mathrm{w}$ ramach drugiego etapu proces konwergencji miałby nabrać wiążącego prawnie charakteru w zakresie rynków pracy, konkurencyjności, otoczenia biznesu, administracji publicznej oraz niektórych aspektów polityki podatkowej ${ }^{45}$.

\section{III.1.1.1. System organów ds. konkurencyjności w strefie euro}

W wyniku dotychczasowych reform zarządzanie strefą euro stało się wprawdzie skuteczne w zakresie koordynacji i nadzoru polityki budżetowej, ale wymagało jeszcze poprawy w dziedzinie konkurencyjności. W związku z tym sygnatariusze raportu zalecali, aby każde państwo członkowskie strefy euro utworzyło własny organ ds. konkurencyjności. Organy takie winny być niezależnymi podmiotami, uprawnionymi m.in. do oceny wysokości wynagrodzeń w państwach członkowskich w zależności od poziomu wydajności pracy, a także monitorowania postępów w zakresie realizacji reform gospodarczych. Pozwoliłoby to poprawić ogólną konkurencyjność w całej strefie euro. Do systemu organów ds. konkurencyjności winny należeć zarówno organy krajowe, jak i Komisja Europejska. Ta ostatnia byłaby odpowiedzialna za koordynację działań organów krajowych. Wyniki takiej koordynacji mogłaby ona potem wykorzystać przy podejmowaniu decyzji w trakcie semestru europejskiego, w szczególności decyzji dotyczących rocznej analizy wzrostu gospodarczego oraz procedury zakłóceń równowagi makroekonomicznej. Każde państwo członkowskie winno samodzielnie określić strukturę organizacyjną krajowego organu ds. konkurencyjności ${ }^{46}$.

\section{III.1.1.2. Usprawnienie i wzmocnienie procedury dotyczącej zakłóceń równowagi makroekonomicznej}

W raporcie zalecano usprawnienie i wzmocnienie procedury dotyczącej zakłóceń równowagi makroekonomicznej, stanowiącej jeden z elementów składowych semestru europejskiego. W tym celu proponowano wykorzystanie tej procedury nie tylko do wykrywania zakłóceń równowagi, ale także do wspierania reform strukturalnych służących promowaniu wzrostu i zatrudnienia zgodnie ze strategią „Europa 2020”. Ponadto procedura taka powinna służyć lepszemu niż dotąd monitorowaniu i przezwyciężaniu zakłóceń w całej strefie euro, a nie tylko w poszczególnych państwach członkowskich. Winna się ona zatem koncentrować zarówno na korekcie szkodliwych deficytów zewnętrznych (np. w postaci nagłego wstrzymania przepływów kapitału), jak i na reformach w tych krajach członkowskich strefy euro, które posiadały zbyt duże i trwałe nadwyżki na rachunku obrotów bieżących, spowodowane zbyt niskim popytem wewnętrznym lub niewielkim potencjałem wzrostu. Przeciwdziałanie tym zjawiskom miałoby niezwykle istotne znaczenie dla zapewnienia równowagi w całej strefie euro ${ }^{47}$.

45 Tamże, s. 8.

46 Tamże, s. 9. Organy ds. konkurencyjności istniały już w tym czasie w Belgii i Holandii.

47 Tamże. W latach 2007-2013 taką nadwyżkę w bilansie obrotów bieżących miała RFN. Była ona spowodowana relatywnie niskimi - w porównaniu z innymi państwami strefy - płacami w Niemczech 
III.1.1.3. Zatrudnienie i kwestie socjalne

Ponieważ pomyślne zakończenie procesu konstytuowania Unii Gospodarczej i Walutowej wymagało m.in. sprawnego funkcjonowania rynków pracy oraz systemów bezpieczeństwa socjalnego we wszystkich państwach strefy euro, kwestie te winny mieć priorytetowe znaczenie dla semestru europejskiego. W związku z tym w raporcie podkreślono, że do podstawowych wyzwań na rynku pracy państw członkowskich należeć powinny m.in.: wzrost zatrudnienia w każdej grupie wiekowej; zapobieganie rozwarstwieniu między pracownikami objętymi daleko idaca ochrona i otrzymujacymi wysokie wynagrodzenie a osobami wytaczonymi z takich przywilejów; redukcja obciążeń podatkowych pracy; indywidualne wsparcie dla osób bezrobotnych w celu umożliwienia im powrotu na rynek pracy, a także poprawa ustawicznego kształcenia i uczenia się. Jeśli chodzi o zagadnienia wykraczające poza rynek pracy, zalecano natomiast, aby zapewnić każdemu obywatelowi dostęp do odpowiedniej edukacji, stworzyć skuteczny system ochrony socjalnej, chroniący przede wszystkim najbardziej wrażliwe grupy spoteczne, zapewniając m.in. minimum ochrony socjalnej, a także przeprowadzić reformę systemów emerytalnych oraz systemów opieki zdrowotnej. Reforma emerytalna winna obejmować dostosowanie wieku emerytalnego do średniej trwania życia. Wśród sformułowanych w raporcie rekomendacji znalazła się także ściślejsza integracja krajowych rynków pracy dzięki ułatwieniu mobilności geograficznej i zawodowej, m.in. przez lepszy system uznawania kwalifikacji, tatwiejszy dostęp do miejsc pracy w sektorze publicznym dla cudzoziemców oraz lepsza koordynacje systemów zabezpieczenia spotecznego ${ }^{48}$.

\section{III.1.1.4. Ściślejsza koordynacja polityk gospodarczych}

Dzięki semestrowi europejskiemu udało się wprawdzie w istotny sposób poprawić koordynację polityk gospodarczych państw strefy euro, jednak należałoby jeszcze uprościć i usprawnić jego przebieg, zwracając szczególną uwagę na cztery kwestie. Po pierwsze, zalecenia przekazywane państwom członkowskim winny być skoncentrowane na priorytetowych reformach służących zwiększeniu wzrostu gospodarczego oraz wspieraniu procesu tworzenia nowych miejsc pracy, a także wykorzystaniu możliwości wynikających z walorów jednolitego rynku. Z drugiej strony zalecenia te powinny zachować charakter polityczny, tak aby państwa cztonkowskie miaty pewien

oraz zbyt niskim jak dla RFN kursem wymiany euro. Konsekwencją tego było zakłócenie równowagi ekonomicznej w całej strefie euro, a tym samym dalsze pogłębienie kryzysu. W 2013 r., gdy Komisja Europejska zaczęła pracować nad projektami zmian ustrojowych w strefie euro, zajęła się także sprawą niemieckiej nadwyżki na rachunku obrotów bieżących. 5 III 2014 r. udzieliła ona rządowi RFN nagany, wzywając go jednocześnie do podjęcia niezbędnych działań mających na celu zwiększenie popytu wewnętrznego w Niemczech, ponieważ dotychczasowa nadwyżka w bilansie obrotów bieżących groziła zachwianiem równowagi w całej strefie euro. Por. J.J.Węc, Relacje polsko-niemieckie w unii Europejskiej i NATO na poczatku XXI w. Próba bilansu, „Prace Komisji Srodkowoeuropejskiej PAU” 2015, t. 23, s. 130-134. 
margines swobody w kwestii konkretnych dziatań, które zamierzają podjać, zaś krajowe programy reform, sporządzane co roku przez państwa członkowskie, winny służyć jako punkt wyjścia do dyskusji na temat planowanych dziatań. Po drugie, sporządzanie okresowych sprawozdań, regularne oceny wzajemne oraz zasada „przestrzegaj lub wyjaśnij” powinny być systematycznie stosowane, zaś rolę koordynatora w tym zakresie mogłaby odgrywać Eurogrupa (etap pierwszy). W tym celu należałoby także jak najlepiej wykorzystać procedurę dotyczącą zakłóceń równowagi makroekonomicznej. Po trzecie, semestr europejski winien być realizowany dwuetapowo, najpierw w skali całej strefy euro (od listopada w roku $n-1$ do lutego w roku $n$ ), a następnie na szczeblu krajowym (od marca do lipca w roku $n)^{49}$. Oznaczało to, że najpierw powinny być formułowane zalecenia dla strefy euro, a dopiero później rekomendacje dla poszczególnych państw członkowskich. Zmiany te autorzy nazywali odnowieniem semestru europejskiego. Po czwarte, roczny cykl semestru europejskiego powinien być osadzony w stabilnych ramach wieloletnich, co wynikało ze zmian wprowadzonych w procesie konwergencjii ${ }^{50}$.

\section{III.1.1.5. Formalizacja procesu konwergencji}

W drugim etapie, ale w perspektywie średniookresowej, wspomniany wyżej proces konwergencji, którego celem byłoby stworzenie bardziej odpornych struktur gospodarczych, powinien „nabrać charakteru wiążącego”. Oznaczałoby to konieczność skodyfikowania przeprowadzonych zmian w prawie Unii Europejskiej. W ten sposób wprowadzona zostałaby współodpowiedzialność wszystkich państw członkowskich za polityki będące przedmiotem wspólnego zainteresowania. W związku z tym w niektórych obszarach konieczna byłaby dalsza harmonizacja przepisów, zaś tam gdzie różne strategie polityczne moga przynieść równie dobre wyniki, stosowane byłyby rozwiązania specyficzne dla danego państwa członkowskiego. Jak wspomniano wyżej, proces konwergencji miałby nabrać charakteru wiążącego w zakresie rynków pracy, konkurencyjności, otoczenia biznesu, administracji publicznej oraz niektórych aspektów polityki podatkowej (np. podstawy opodatkowania osób prawnych). Ponadto procedura dotycząca zakłóceń równowagi makroekonomicznej winna być wykorzystywana nie tylko jako narzędzie zapobiegania takim zakłóceniom i ich korygowania, ale także jako instrument wspierania i monitorowania procesu reform w poszczególnych państwach strefy euro. Tylko znacząca i trwała konwergencja zapewniająca podobny poziom elastyczności gospodarek winna być warunkiem dostępu do mechanizmu amortyzacji wstrząsów, który w przyszłości należałoby w związku z tym ustanowić dla całej strefy euro ${ }^{51}$.

\footnotetext{
49 Rok $n-1$ to rok poprzedzający, zaś rok $n$ to rok bieżący, por. tamże, s. 24 (Zatącznik nr 2: Bardziej zintegrowany europejski semestr).

50 Tamże, s. 10-11.

51 Tamże, s. 11.
} 


\section{III.1.2. Unia Finansowa}

Sygnatariusze raportu podkreślali, że Unia Gospodarcza oraz Unia Finansowa winny się wzajemnie uzupełniać. Dlatego prace zmierzające do ich ustanowienia powinny stanowić najwyższy priorytet pierwszego etapu planowanej reformy. Unia Finansowa miałaby zapewnić petna jednolitość systemu finansowego, w przeciwnym razie transmisja impulsów wynikajacych z decyzji polityki pieniężnej (np. zmian polityki dotyczacej stóp procentowych) będzie się różnić w poszczególnych państwach cztonkowskich. Właśnie taka sytuacja miała miejsce w czasie kryzysu zadłużeniowego strefy euro, doprowadzając do pogłębienia się różnic gospodarczych pomiędzy jej państwami członkowskimi. Unia Finansowa winna się składać z Unii Bankowej oraz Unii Rynków Kapitałowych. Należałoby zatem dokończyć budowę Unii Bankowej oraz rozpocząć prace nad ustanowieniem Unii Rynków Kapitałowych. Obydwa elementy składowe Unii Finansowej winny zostać ustanowione w ramach pierwszego etapu planowanej reformy ustrojowej ${ }^{52}$.

\section{III.1.2.1. Unia Bankowa}

Autorzy raportu wzywali również do zakończenia procesu konstytuowania Unii Bankowej. Antycypując, że z dniem 1 stycznia 2016 r. Jednolity Fundusz Restrukturyzacji i Uporządkowanej Likwidacji uzyska zdolność operacyjną̧33, postulowali podjęcie czterech dalszych działań. Po pierwsze, dokonanie pełnej implementacji do prawa krajowego tzw. dyrektywy BRRD, mającej kluczowe znaczenie dla dzielenia się ryzykiem z sektorem prywatnym. Po drugie, wszystkie państwa uczestniczące w SSM oraz SRM winny podpisać porozumienia o uruchomieniu linii kredytowej, czyli mechanizmu finansowania pomostowego wspomagającego SRF. Mechanizm taki miał zapewnić SRF w ośmioletnim okresie przejściowym wystarczające środki finansowe na pokrycie ewentualnych kosztów restrukturyzacji i uporządkowanej likwidacji banków znajdujących się w trudnej sytuacji. Po trzecie, niezbędne byłoby utworzenie Wspólnego Mechanizmu Ochronnego związanego z SRF przez wykorzystanie do tego celu linii kredytowej z Europejskiego Mechanizmu Stabilności. Po czwarte, należałoby ustanowić Europejski System Gwarantowania Depozytów (European Deposit Insurance Scheme - EDIS) jako trzeci filar Unii Bankowej. Kluczowym elementem EDIS miałby być wspólny fundusz finansowy, zasilany ze składek uiszczanych ex ante przez należące do niego banki, analogicznie jak w przypadku Jednolitego Funduszu Restrukturyzacji i Uporządkowanej Likwidacji. Jednocześnie sygnatariusze raportu wskazywali na nowe potencjalne rodzaje ryzyka w sektorze bankowym, w tym także ryzyko powstawania tzw. równoległego systemu bankowego. W tym celu proponowali wzmocnienie

\section{Tamże, s. 13.}

53 Jak wspomniano wyżej, spośród trzech planowanych filarów Unii Bankowej do 1 I 2016 r. zdolność operacyjną uzyskały jedynie Jednolity Mechanizm Nadzorczy oraz Jednolity Mechanizm Restrukturyzacji i Uporządkowanej Likwidacji. 
unijnych instytucji makroostrożnościowych, w szczególności Europejskiej Rady ds. Ryzyka Systemowego (European Systemic Risk Board - ESRB) ${ }^{54}$.

Warto zauważyć, że propozycja ustanowienia Europejskiego Systemu Gwarantowania Depozytów oznaczała zmianę dotychczasowego stanowiska Unii Europejskiej w sprawie struktury trzeciego filaru Unii Bankowej. Pięciu przewodniczących opowiedziało się bowiem za rezygnacją z przewidywanej dotąd harmonizacji krajowych systemów gwarancji depozytów na rzecz ich, przynajmniej częściowej, unifikacji i uwspólnotowienia. Argumentowali oni, że dyrektywa DGSD doprowadziła wprawdzie do większej harmonizacji, zwłaszcza w zakresie prefinansowania systemów krajowych, ale nadal dopuszczała pewien margines swobody na poziomie krajowym, który winien zostać poddany przegladowi. Wszystkie banki uczestniczące w Unii Bankowej powinny mieć bowiem równe warunki działania ${ }^{55}$. Ponadto EDIS mógłby o wiele skuteczniej zwiększyć odporność Unii Europejskiej na przyszłe kryzysy. Autorzy raportu proponowali, aby do jego ustanowienia wykorzystać możliwości, jakie dają obowiązujące przepisy. Jedną z nich byłoby utworzenie EDIS jako systemu reasekuracji na poziomie europejskim dla krajowych systemów gwarantowania depozytów ${ }^{56}$.

\section{III.1.2.2. Unia Rynków Kapitałowych}

Obok dokończenia budowy Unii Bankowej priorytetowe znaczenie dla procesu konstytuowania Unii Finansowej miało ustanowienie Unii Rynków Kapitałowych. Ta nowa struktura winna zapewniać m.in. zwiększenie zróżnicowania źródeł finansowania i wzmocnienie mechanizmu transgranicznego podziału ryzyka, a także powinna stanowić sui generis bufor chroniący przed wstrząsami systemowymi w sektorze finansowym. Unia Rynków Kapitałowych umożliwiłaby zatem pozyskiwanie przez przedsiębiorstwa, w tym także przez małe i średnie firmy, środków finansowych na rynkach kapitałowych niejako w uzupełnieniu kredytów bankowych. Wzmocniłaby ona także mechanizm transgranicznego podziatu ryzyka przez pogłębienie integracji rynków obligacji i akcji, co miałoby bardzo duże znaczenie, zwłaszcza że ten ostatni rynek odgrywa kluczowa role w stabilizowaniu wstrzasów gospodarczych. Prawdziwie zintegrowany rynek kapitałowy stanowiłby bufor chroniący przed wstrząsami systemowymi w sektorze finansowym i ułatwiałby dzielenie się ryzykiem z sektorem prywatnym w poszczególnych państwach członkowskich. Ponieważ jednak ściślejsza integracja rynków kapitałowych i stopniowe znoszenie istniejących barier krajowych mogłyby stwarzać nowe zagrożenia dla stabilności finansowej, zdaniem autorów raportu konieczne byłoby także ustanowienie jednolitego europejskiego organu nadzoru rynków kapitałowych ${ }^{57}$.

\footnotetext{
Tamże, s. 14.
}

55 Tamże, s. 13-14. W toku negocjacji nad dyrektywą DGSD, głównie pod naciskiem Niemiec, zgodzono się jedynie na przepisy harmonizujące, czyli de facto na koordynację działalności krajowych funduszy gwarancyjnych, a nie na ich unifikację. Por. Dyrektywa Parlamentu Europejskiego i Rady 2014/49/ UE z dnia 16 kwietnia 2014 r. w sprawie systemów..., s. 149-178.

56 Komisja Europejska, Dokończenie budowy europejskiej Unii Gospodarczej i Walutowej..., s. 13.

57 Tamże, s. 14. 


\section{III.1.3. Unia Fiskalna}

Jednym z wniosków wynikających z przebiegu kryzysu zadłużeniowego strefy euro było to, iż polityki budżetowe mają zasadnicze znaczenie dla wszystkich państw należących do Unii Walutowej. Wspólna polityka pieniężna ukierunkowana na stabilność cen nie gwarantuje bowiem, że Unia Gospodarcza i Walutowa będzie zawsze prawidłowo funkcjonować. Niezrównoważone polityki budżetowe zagrażają zarówno stabilności cen w Unii Europejskiej, jak i szkodzą stabilności finansowej, ponieważ powodują efekt domina wśród państw cztonkowskich i fragmentację rynków finansowych. W związku z tym - zdaniem autorów raportu - odpowiedzialnie prowadzone polityki budżetowe państw członkowskich winny spełnić dwa warunki: po pierwsze, muszą one gwarantować zdolność obsługi długu publicznego i zapewniać działanie automatycznych stabilizatorów fiskalnych w celu zmniejszenia wstrząsów gospodarczych w danym państwie; po drugie, suma sald budżetowych poszczególnych państw powinna umożliwiać właściwy kurs polityki budżetowej na poziomie strefy euro jako całości ${ }^{58}$.

\section{III.1.3.1. Europejska Rada Budżetowa}

Uchwalone i wprowadzone w życie w ostatnich latach pakiety aktów prawnych w sprawie zarządzania gospodarczego, czyli sześciopak, dwupak oraz pakt fiskalny, znacznie usprawnily koordynację ex ante polityk budżetowych w całej Unii Gospodarczej i Walutowej oraz wzmocniły nadzór nad tymi państwami, które popadają w trudności finansowe. Okazało się to jednak niewystarczające. Dlatego sygnatariusze raportu opowiedzieli się za dalszym wzmocnieniem mechanizmu koordynacji poprzez ustanowienie jeszcze w pierwszym etapie reformy Europejskiej Rady Budżetowej jako organu o kompetencjach doradczych. Miałaby ona koordynować i wspierać prace krajowych rad budżetowych, a także przeprowadzać niezależną ocenę budżetów państw członkowskich oraz ich wykonanie pod kątem celów i zaleceń określonych w unijnych ramach zarządzania budżetowego. Opinie Europejskiej Rady Budżetowej winny być uwzględniane przy podejmowaniu przez Komisję Europejską decyzji dotyczących semestru europejskiego ${ }^{59}$.

\section{III.1.3.2. Fiskalny mechanizm stabilizacyjny}

Aby lepiej radzić sobie ze wstrząsami gospodarczymi, których złagodzenie nie jest możliwe wyłącznie na poziomie krajowym, autorzy raportu proponowali również ustanowienie w drugim etapie reformy, ale w dłuższej perspektywie czasowej, wspólnego fiskalnego mechanizmu stabilizacyjnego strefy euro umożliwiającego lepszą amortyzację dużych wstrząsów makroekonomicznych. Nie mówili oni już zatem o mechanizmie zdolności fiskalnej (fiscal capacity), jak Van Rompuy w swoim raporcie z grudnia

\footnotetext{
58 Tamże, s. 16.

59 Tamże, s. 16, 22.
} 
2012 r., lecz jedynie o fiskalnym mechanizmie stabilizacyjnym (fiscal stabilisation function). Jednak cele obu instrumentów miały być podobne, czyli amortyzacja dużych wstrząsów makroekonomicznych, a w konsekwencji zwiększenie odporności całej Unii Gospodarczej i Walutowej. W ślad za tym postulowali oni powołanie specjalnej grupy ekspertów, która opracowałaby zasady funkcjonowania takiego mechanizmu. Punktem wyjścia w jej pracach winny być następujące założenia: po pierwsze, mechanizm stabilizacji makroekonomicznej powinien być powołany w ramach prawnych Unii Europejskiej, a nie na mocy umowy międzyrządowej; po drugie, musiałby on być spójny z istniejącymi ramami budżetowymi Unii oraz procedurami służącymi koordynacji polityk gospodarczych; po trzecie, miałby on być otwarty i przejrzysty dla wszystkich państw członkowskich Unii Europejskiej; po czwarte, nie mógłby to być instrument zarządzania kryzysowego, ponieważ taką funkcję pełni już Europejski Mechanizm Stabilności. Ustanowienie fiskalnego mechanizmu stabilizacyjnego strefy euro stanowiłoby zwieńczenie procesu reform, przy czym wcześniej należałoby osiągnąć wysoki poziom konwergencji gospodarczej, integracji finansowej oraz koordynacji polityk budżetowych (m.in. wspólne podejmowanie decyzji w sprawie krajowych budżetów $)^{60}$.

\section{III.1.4. W kierunku Unii Politycznej: demokratyczna rozliczalność, zasadność i wzmocnienie instytucjonalne}

W celu legitymizacji wspomnianych wyżej zmian ustrojowych zalecano, aby w strefie euro doszło do rozszerzenia kompetencji Parlamentu Europejskiego i parlamentów narodowych; wzmocnienia reprezentacji Unii Europejskiej i strefy euro na forum międzynarodowych instytucji finansowych; włączenia porozumień międzyrządowych dotyczących strefy euro do prawa pierwotnego Unii Europejskiej; wmocnienia pozycji Eurogrupy m.in. przez ustanowienie urzędu jej stałego przewodniczącego, a także utworzenia organu na kształt ministerstwa skarbu, odpowiedzialnego za podejmowanie decyzji w dziedzinie polityki fiskalnej.

\section{III.1.4.1. Parlament Europejski i parlamenty narodowe}

W związku ze wspomnianą wyżej reorganizacją semestru europejskiego już w pierwszym etapie planowanej reformy winny nastąpić trzy zmiany: po pierwsze, należałoby wzmocnić kontrolę parlamentarną w procedurze odnowionego semestru europejskiego; po drugie, powinno nastąpić zacieśnienie współpracy pomiędzy Parlamentem Europejskim a parlamentami narodowymi w ramach tzw. Europejskiego Tygodnia Parlamentarnego; po trzecie, parlamenty narodowe winny bardziej systematycznie korzystać z tzw. prawa do wezwania komisarza zgodnie z przepisami dwupaku ${ }^{61}$.

Jeśli chodzi o wzmocnienie kontroli parlamentarnej w procedurze semestru europejskiego, to miałaby ona polegać na tym, że w pierwszej fazie semestru (od listopada

60 Tamże, s. 17.

${ }_{61}$ Tamże, s. 19. 
roku $n$ - 1 do lutego roku $n$ ) Komisja Europejska mogłaby uczestniczyć w debacie plenarnej w Parlamencie Europejskim przed publikacją rocznej analizy wzrostu gospodarczego, a następnie kontynuować tę debatę po przyęciu analizy. Wraz z przedłożeniem rocznej analizy wzrostu Komisja Europejska przedstawiałaby stosowne zalecenia dotyczące podjęcia działań w strefie euro, a także wykaz państw członkowskich, których sytuacja wymagałaby przeprowadzenia procedury dotyczącej zakłóceń równowagi makroekonomicznej. Po przedstawieniu przez Komisję Europejską zaleceń dla poszczególnych państw można by przeprowadzić drugą debatę plenarną, zgodnie z odpowiednimi przepisami sześciopaku dotyczącymi dialogu gospodarczego. Ponadto do dialogu tego, zgodnie z postanowieniami sześciopaku oraz dwupaku, należałoby także włączyć różne formacje Rady Unii Europejskiej oraz Eurogrupę. Druga faza semestru europejskiego (od marca do lipca roku $n$ ) byłaby poświęcona przeglądowi i ocenie wyników oraz polityk państw członkowskich w świetle ustalonych priorytetów. Rozpoczynałaby się ona od publikacji sprawozdań Komisji Europejskiej na temat poszczególnych państw, zaś kończyłaby się przyjęciem dla nich stosownych zaleceń. W tej fazie państwa członkowskie winny systematycznie angażować parlamenty narodowe do dyskusji na temat piorytetów krajowych ${ }^{62}$.

62 Tamże, s. 24 (Zatacznik nr 2: Bardziej zintegrowany europejski semestr). Od 1 I 2012 r. do opublikowania raportu pięciu przewodniczących w dniu 22 VI 2015 r. procedura semestru europejskiego wyglądała następująco. W listopadzie roku poprzedniego Komisja Europejska przedstawiała roczną analizę wzrostu gospodarczego oraz sprawozdanie ostrzegawcze na temat ewentualnych nierównowag makroekonomicznych. To pierwsze sprawozdanie zawierało m.in. cele i priorytety w polityce gospodarczej i finansowej w nadchodzącym roku budżetowym oraz ocenę realizacji przez państwa członkowskie ubiegłorocznych zaleceń. Roczna analiza wzrostu gospodarczego dotyczyła trzech elementów polityki gospodarczej: polityki makroekonomicznej i budżetowej, reform strukturalnych oraz środków służących pobudzeniu wzrostu gospodarczego. W sprawozdaniu ostrzegawczym Komisja Europejska przedstawiała sytuację makroekonomiczną w poszczególnych państwach członkowskich oraz wymieniała te spośród nich, dla których należałoby przeprowadzić szczegółową ocenę sytuacji wobec dużego ryzyka wystąpienia nierównowag makroekonomicznych. Jeśli chodzi o część semestru europejskiego poświęconą analizie wzrostu gospodarczego, to zalecenia Komisji Europejskiej stanowiły podstawę do debaty na forum Parlamentu Europejskiego, która kończyła się uchwaleniem rezolucji, a także dyskusji podczas posiedzenia Rady Unii Europejskiej, która przyjmowała raport na temat priorytetów w nadchodzącym roku budżetowym. Następnie w oparciu o ten raport Rada Europejska podczas swojego wiosennego posiedzenia (luty/marzec) przyjmowała konkluzje zatwierdzające te priorytety. W połowie kwietnia (a od 2015 r. w lutym) każdego roku państwa członkowskie Unii Europejskiej miały przedkładać do oceny Komisji Europejskiej krajowe programy reform oraz programy stabilności (państwa strefy euro) lub programy konwergencji (państwa spoza strefy euro). Krajowe programy reform określały m.in. plany państw członkowskich w zakresie reform strukturalnych oraz środków służących pobudzeniu wzrostu gospodarczego i zatrudnienia. Natomiast programy stabilności i programy konwergencji obejmowały krajowe zobowiązania służące zapewnieniu solidnych i zrównoważonych finansów publicznych. Na przełomie maja i czerwca (a od 2015 r. w maju) danego roku Komisja Europejska, po uprzednim przeprowadzeniu wspomnianej wyżej oceny, przedstawiała Radzie Unii Europejskiej projekt zaleceń dla poszczególnych państw członkowskich, wskazując na ich postępy i ewentualne zaniechania w realizacji uzgodnionych działań. Po przedyskutowaniu i zatwierdzeniu tych zaleceń przez Radę Europejską podczas jej letniego (czerwiec) posiedzenia, a następnie ich przyjęciu (wraz z opinią na temat programów reform i stabilności lub programów konwergencji) przez Radę ds. Gospodarki i Finansów (lipiec) państwa członkowskie musiały uwzględnić ewentualne wskazówki w projektach swoich budżetów na następny rok. Ostatnim elementem semestru była debata na forum Parlamentu 
Druga spośród proponowanych zmian legitymizacyjnych sprowadzałaby się do aktywniejszego włączania przedstawicieli parlamentów narodowych do debaty na temat priorytetów polityki gospodarczej w Unii Gospodarczej i Walutowej. Jednocześnie przedstawiciele Komisji Europejskiej i Rady Unii Europejskiej mogliby uczestniczyć w posiedzeniach organizowanych w ramach Europejskiego Tygodnia Parlamentarnego, dotyczących zarówno krajowych debat parlamentarnych na temat zaleceń skierowanych do poszczególnych państw członkowskich, jak i rocznej procedury budżetowej. Ponadto parlamenty narodowe winny być w większym stopniu zaangażowane w przyjmowanie krajowych programów reform i programów stabilności państw należących do strefy euro. Trzecia z postulowanych zmian winna natomiast polegać na tym, aby zachęcać parlamenty narodowe do bardziej systematycznego korzystania z określonego w dwupaku prawa do wezwania komisarza w celu przedstawienia opinii Komisji Europejskiej na temat projektu planu budżetowego lub jej zaleceń dla państwa członkowskiego podlegającego procedurze nadmiernego deficytu ${ }^{63}$.

\section{III.1.4.2. Eurogrupa}

Już w pierwszym etapie reformy ustrojowej należałoby wzmocnić pozycję przewodniczącego Eurogrupy oraz zwiększyć środki, jakimi on dysponuje. Byłoby to bowiem w pełni uzasadnione m.in. z powodu rozszerzenia uprawnień Eurogrupy w odnowionym semestrze europejskim. W drugim etapie reformy, ale w perspektywie długookresowej, można by natomiast rozważyć ustanowienie urzędu stałego przewodniczącego Eurogrupy ${ }^{64}$.

\section{III.1.4.3. Umocnienie reprezentacji zewnętrznej strefy euro}

Już w pierwszym etapie planowanej reformy ustrojowej winien być również zainicjowany, a następnie kontynuowany, proces umacniania reprezentacji zewnętrznej strefy euro. Dzięki m.in. dużemu znaczeniu gospodarczemu i finansowemu Unii Europejskiej oraz jednolitej polityce pieniężnej strefy euro decyzje polityczne i rozwój gospodarczy w jej ramach nabierały coraz bardziej istotnego znaczenia dla gospodarki światowej. Mimo to strefa euro nie była nadal reprezentowana przez wspólną delegację na forum międzynarodowych instytucji finansowych. Skutkowało to tym, że nie mogła ona w pełni korzystać ze swojej siły politycznej i gospodarczej, gdyż każde państwo członkowskie wypowiadało się jedynie we własnym imieniu. Szczególnie drastyczny

Europejskiego, kończąca się uchwaleniem rezolucji na temat realizacji przez państwa członkowskie priorytetów na dany rok budżetowy. Por. Ministerstwo Gospodarki RP, Semestr europejski. Okres oceny i koordynacji polityki gospodarczej w UE, Warszawa 2014, s. 8-9; Semestr europejski. Przebieg cyklu koordynacji na poziomie Unii i Polski (2011-2016) (stan prawny na 30 listopada 2015), s. 1-5, Ośrodek Informacji i Dokumentacji Europejskiej. Biblioteka Sejmowa, [online] https://oide.sejm.gov.pl/. Na temat harmonogramu semestru europejskiego w 2011 r. por. J.J. Węc, Pierwsza polska prezydencja..., s. 133-134.

63 Komisja Europejska, Dokończenie budowy europejskiej Unii Gospodarczej i Walutowej..., s. 19.

64 Tamże, s. 20. 
był - zdaniem autorów raportu - brak wspólnej reprezentacji strefy euro w relacjach z Międzynarodowym Funduszem Walutowym $(\mathrm{MFW})^{65}$.

\section{III.1.4.4. Włączenie porozumień międzyrządowych do prawa Unii Europejskiej}

W szczytowym momencie kryzysu zadłużeniowego niektóre decyzje o dalekosiężnych skutkach musiały być podjęte w drodze porozumień międzyrządowych, ponieważ w ten sposób łatwiej było przyspieszyć proces decyzyjny oraz przezwyciężyć sprzeciw rządów niektórych państw członkowskich. Dotyczyło to w szczególności paktu fiskalnego, części paktu euro plus, umowy międzyrządowej w sprawie ustanowienia Jednolitego Funduszu Restrukturyzacji i Uporządkowanej Likwidacji, a także porozumienia o utworzeniu Europejskiego Mechanizmu Stabilności. Obecnie - zdaniem sygnatariuszy raportu nadszedł czas, aby w etapie drugim reformy, ale w perspektywie średniookresowej, włączyć postanowienia tych międzyrządowych umów do prawa Unii Europejskiej ${ }^{66}$.

\section{III.1.4.5. Organ skarbowy strefy euro}

Jedną z konsekwencji ustanowienia Unii Fiskalnej winno być także utworzenie w drugim etapie reformy ustrojowej organu skarbowego strefy euro, przy zapewnieniu demokratycznej rozliczalności i legalności. Organ taki miałby być platformą wspólnego podejmowania decyzji w polityce fiskalnej. Nie oznaczałoby to jednak centralizacji wszystkich aspektów polityki przychodów i wydatków. W dyspozycji państw członkowskich strefy euro nadal pozostawałyby bowiem decyzje dotyczące polityki podatkowej i podziału wydatków budżetowych ${ }^{67}$.

Należy podkreślić, że raport pięciu przewodniczących był nie tylko bardziej szczegółowy, ale także szedł o wiele dalej aniżeli raport Van Rompuya sprzed dwóch i pół roku. $\mathrm{O}$ ile ten ostatni nadawał wyraźny kierunek reformie ustrojowej strefy euro i całej Unii Gospodarczej i Walutowej, o tyle raport z 22 czerwca 2015 r. przedstawiał już bardzo konkretne cele, instrumenty, metody oraz precyzyjny harmonogram realizacji reformy. Warto również zauważyć, że raport Van Rompuya zupełnie pomijał jako nieskuteczną niemiecką propozycję rozwiązania kryzysu zadłużeniowego strefy euro poprzez przekształcenie Unii Europejskiej w Unię Polityczną. Natomiast raport pięciu przewodniczących mówił wprost nie tylko o możliwości, lecz także o konieczności ustanowienia zrębów Unii Politycznej w ramach procesu konstytuowania rzeczywistej Unii Gospodarczej i Walutowej.

\footnotetext{
65 Tamże, s. 19-20.

66 Tamże, s. 20.

67 Tamíe.
} 


\section{III.2. Realizacja zmian ustrojowych}

\section{III.2.1. Rada Europejska}

W dniach 25-26 czerwca 2015 r. Rada Europejska zapoznała się z raportem pięciu przewodniczących, a następnie zwróciła się do Rady Unii Europejskiej o szybkie przeanalizowanie jego założeń ${ }^{68} .15$ października tegoż roku Rada Europejska ostatecznie zaakceptowała raport.

Dwa miesiące później, w konkluzjach uchwalonych w dniach 17-18 grudnia 2015 r., wezwała ona Radę Unii Europejskiej do rychłego rozpatrzenia wniosków Komisji Europejskiej opublikowanych w związku z przedłożonym raportem. Zwróciła także uwagę, że szczególnie szybkiego uregulowania wymagają trzy kwestie: poprawa skuteczności zarządzania gospodarczego i budżetowego w celu zwiększenia konkurencyjności, konwergencji i stabilności; wzmocnienie zewnętrznej reprezentacji strefy euro, co lepiej odzwierciedlałoby jej znaczenie w światowej gospodarce, a także dokończenie procesu konstytuowania Unii Bankowej w celu umocnienia stabilności finansowej strefy euro. Rada Europejska zobowiązała również Radę Unii Europejskiej, aby ta do czerwca 2016 r. przygotowała i przedłożyła sprawozdanie z przebiegu dotychczasowych prac nad reformą. Ponadto zapowiedziała, że nie później niż przed końcem 2017 r. sama ponownie zajmie się sprawą reformy ${ }^{69}$.

Zgodnie z zapowiedzią Rada Europejska 28 czerwca 2016 r. zapoznała się z dotychczasowym przebiegiem prac nad reformą ustrojową strefy euro. Pozytywnie oceniła postępy w działaniach na rzecz dokończenia procesu konstytuowania Unii Gospodarczej i Walutowej, w tym Unii Bankowej, a także zaapelowała o ich kontynuację. Zatwierdziła również zalecenia Rady Unii Europejskiej dotyczące utworzenia w strefie euro krajowych rad ds. konkurencyjności ${ }^{70}$.

\section{III.2.2. Komisja Europejska}

Już 28 stycznia 2015 r. Komisja Europejska rozpoczęła prace nad projektem Unii Rynków Kapitałowych, która winna stanowić drugi - obok Unii Bankowej - element składowy Unii Finansowej. Ta nowa struktura mogła obejmować wszystkie państwa członkowskie Unii Europejskiej. Jej działalność winna się przyczynić m.in. do obniżenia kosztów pozyskania kapitału, w szczególności dla małych i średnich przedsiębiorstw, a także zwiększenia atrakcyjności Unii Europejskiej jako obszaru do inwestowania. 30 września 2015 r., czyli kilkanaście tygodni po wydaniu raportu

68 Posiedzenie Rady Europejskiej w dniach 25-26 czerwca 2015 r. Konkluzje, Bruksela, 26 VI 2015 r., EUCO 22/15, s. 8.

69 Posiedzenie Rady Europejskiej $w$ dniu 15 października 2015 r. Konkluzje, Bruksela, 16 X 2015 r., EUCO 26/15, s. 6; Posiedzenie Rady Europejskiej w dniach 17-18 grudnia 2015 r. Konkluzje, Bruksela, 18 XII 2015 r., EUCO 28/15, s. 5.

70 Posiedzenie Rady Europejskiej w dniu 28 czerwca 2016 r. Konkluzje, Bruksela, 28 VI 2016 r., EUCO 26/16, s. 6 . 
pięciu przewodniczących, Komisja Europejska opublikowała komunikat skierowany do Parlamentu Europejskiego, Rady Unii Europejskiej, Komitetu Ekonomiczno-Społecznego i Komitetu Regionów zawierający podstawowe działania priorytetowe, których realizacja miała doprowadzić do ustanowienia do 2019 r. Unii Rynków Kapitałowych ${ }^{71}$.

Wkrótce po zaakceptowaniu przez Radę Europejską raportu pięciu przewodniczących, 21 października 2015 r. Komisja Europejska opublikowała dwa kolejne komunikaty skierowane do Parlamentu Europejskiego, Rady Unii Europejskiej oraz Europejskiego Banku Centralnego. Pierwszy z nich dotyczył realizacji pierwszego okresu reformy oraz działań przygotowawczych do drugiego okresu, zaś drugi komunikat był poświęcony sprawie ustanowienia jednolitej reprezentacji państw strefy euro na forach międzynarodowych.

Spośród działań, które należało zrealizować w pierwszym okresie reformy (do 30 czerwca 2017 r.), Komisja Europejska zwróciła uwagę na pięć kwestii: po pierwsze, reorganizację semestru europejskiego według harmonogramu załączonego do analizowanego komunikatu (Unia Gospodarcza) ${ }^{72}$; po drugie, ustanowienie krajowych rad ds. konkurencyjności (Unia Gospodarcza); po trzecie, utworzenie Europejskiej Rady Budżetowej (Unia Fiskalna); po czwarte, wzmocnienie zewnętrznej reprezentacji strefy euro (legitymizacja); po piąte, dalsze prace zmierzające do powołania do życia Unii Finansowej, zwłaszcza utworzenia Europejskiego Systemu Gwarantowania Depozytów (Unia Finansowa ${ }^{73}$. Odnosząc się do tej ostatniej sprawy, Komisja Europejska zastrzegła sobie, że wykorzysta wszystkie traktatowe uprawnienia, aby zapewnić jak najszybszą pełną implementację dyrektyw BRRD i DGSD przez państwa członkowskie. Wezwała kraje uczestniczące w Unii Bankowej, aby do 30 listopada 2015 r. ratyfikowały umowę międzyrządową o przekazywaniu i uwspólnianiu składek na rzecz SRF, a także zachęciła je do uzgodnienia dwóch ważnych porozumień: o utworzeniu mechanizmu finansowania pomostowego dla SRF oraz o powołaniu do życia Wspólnego Mechanizmu Ochronnego związanego z $\mathrm{SRF}^{74}$.

${ }^{71}$ Komisja Europejska, Komunikat Komisji do Parlamentu Europejskiego, Rady, Europejskiego Komitetu Ekonomiczno-Spotecznego i Komitetu Regionów „Plan dziatania na rzecz tworzenia unii rynków kapitatowych", Bruksela, 30 IX 2015 r., COM(2015) 468 wersja ostateczna, s. 1-36. Analizę komunikatu por. Komisja Europejska - Publikacja "Planu dziatania na rzecz tworzenia unii rynków kapitalowych", „Przegląd Spraw Europejskich” 2015, nr 8/9, s. 7-9. Por. też Komisja Europejska - początek prac nad projektem unii rynków kapitatowych, „Przegląd Spraw Europejskich” 2015, nr 1, s. 8-9.

72 Generalnie rzecz biorąc, zmiany w odnowionym semestrze europejskim sprowadzały się do zaleceń zawartych w raporcie pięciu przewodniczących, zakładających m.in. podział semestru na dwie fazy oraz wzmocnienie w nim uprawnień Parlamentu Europejskiego i parlamentów narodowych. Por. Komisja Europejska, Komunikat Komisji do Parlamentu Europejskiego, Rady oraz Europejskiego Banku Centralnego w sprawie dziatań na rzecz dokończenia budowy unii gospodarczej i walutowej, Bruksela, $21 \mathrm{X}$ 2015 r., $\operatorname{COM}(2015) 600$ wersja ostateczna, s. 20.

73 Tamże, s. 3. W ślad za tym Parlament Europejski miał podjąć także działania zmierzające do legitymizacji wspomnianych zmian ustrojowych, głównie w zakresie zarządzania gospodarczego na szczeblu Unii Europejskiej.

74 Tamże, s. 14-16. 
Jeśli chodzi o drugi okres reformy (od 1 lipca 2017 r.), Komisja Europejska zajęła się głównie poprzedzającymi go pracami przygotowawczymi. Podkreśliła, że rok 2016 będzie miał przełomowe znaczenie dla uzgodnienia środków, które pozwolą zakończyć budowę struktury gospodarczej i instytucjonalnej Unii Gospodarczej i Walutowej. W związku z tym instytucje Unii Europejskiej i państwa członkowskie winny uzgodnić i podjąć działania mające na celu zapewnienie do połowy 2016 r. pełnej operacyjności systemowi organów ds. konkurencyjności oraz Europejskiej Radzie Budżetowej. Komisja Europejska zapowiedziała także powołanie w połowie 2016 r. grupy ekspertów $w$ celu zbadania prawnych, gospodarczych i politycznych warunków wstępnych, dla opracowywania bardziej dtugofalowych propozycji opisanych w raporcie pięciu przewodniczących ${ }^{75}$.

Drugi komunikat Komisji Europejskiej z 21 października 2015 r. zawierał szczegółowy plan wzmocnienia zewnętrznej reprezentacji strefy euro głównie na forum MFW jako kluczowej organizacji międzynarodowej globalnego zarządzania gospodarczego. Wydawało się to w pełni uzasadnione nie tylko z powodu dużego dotąd rozproszenia zewnętrznej reprezentacji strefy euro w MFW, ale także w związku z planowanym właśnie ustanowieniem Unii Gospodarczej, Unii Finansowej i Unii Fiskalnej w ramach UGiW. Miał to być również wyraz legitymizacji przedsięwziętych zmian ustrojowych w strefie euro ${ }^{76}$.

Równocześnie ze wspomnianymi komunikatami 21 października 2015 r. Komisja Europejska wydała trzy wnioski ustawodawcze odnoszące się kolejno do Unii Gospodarczej, Unii Fiskalnej oraz zewnętrznej reprezentacji strefy euro. Celem pierwszego wniosku było uchwalenie przez Radę Unii Europejskiej zalecenia w sprawie ustanowienia w strefie euro krajowych rad ds. konkurencyjności. Wniosek był wprawdzie skierowany do państw strefy euro, ale do powołania podobnych organów zachęcono także pozostałe państwa członkowskie Unii Europejskiej. Każde państwo winno powołać jedną radę ds. konkurencyjności. Krajowe rady ds. konkurencyjności powinny współpracować z Komisją Europejską w ramach procedury semestru europejskiego, a także $\mathrm{z}$ radami ds. konkurencyjności w innych państwach członkowskich w celu koordynacji stanowisk. Miały one publikować swoje analizy i opinie w sprawozdaniu rocznym ${ }^{77}$. Drugi wniosek dotyczył wydania przez Komisję Europejską decyzji w sprawie ustanowienia Europejskiej Rady Budżetowej. Był on adresowany wyłącznie do państw członkowskich strefy euro. Europejska Rada Budżetowa winna być samodzielnym gremium funkcjonującym przy Komisji Europejskiej. Miała pełnić funkcję doradczą w ramach procedury wielostronnego nadzoru w strefie euro oraz ściśle współpracować z krajowymi radami polityki budżetowej państw członkowskich ${ }^{78}$. Trzeci wniosek ustawodawczy

75 Tamże, s. 17-18.

76 Komisja Europejska, Komunikat Komisji do Parlamentu Europejskiego, Rady i Europejskiego Banku Centralnego „Plan dziatania na rzecz bardziej spójnej zewnętrznej reprezentacji strefy euro na forach międzynarodowych", Bruksela, 21 X 2015 r., COM(2015) 602 wersja ostateczna, s. 1-12.

77 Komisja Europejska, Wniosek. Zalecenie Rady w sprawie ustanowienia w strefie euro krajowych rad ds. konkurencyjności, Bruksela, 21 X 2015 r., COM(2015) 601 wersja ostateczna, s. 1-6.

78 Komisja Europejska, Wniosek. Decyzja Komisji (UE) 2015/1937 z dnia 21 października 2015 r. ustanawiająca niezależna doradczą Europejska Radę Budżetową, Dz.U. UE L, 2015, nr 282, s. 37-40. 
odnosił się natomiast do decyzji Rady Unii Europejskiej w sprawie ustanowienia najpóźniej do 2025 r. jednolitej reprezentacji strefy euro w MFW na podstawie art. 138 TFUE. Reprezentacja ta miała się opierać na następujących zasadach: po pierwsze, w Radzie Gubernatorów oraz w Międzynarodowym Komitecie Walutowym i Finansowym MFW poglądy strefy euro miał przedstawiać przewodniczący Eurogrupy; po drugie, w Radzie Wykonawczej MFW strefę euro powinien reprezentować dyrektor wykonawczy grupy państw strefy euro, po ustanowieniu jednej lub kilku grup państw sktadajacych się tylko z państw cztonkowskich strefy euro, przy czym dyrektor ten miatby być wybierany na wniosek przewodniczącego Eurogrupy zgodnie z procedurą art. 2 protokołu nr 14 w sprawie Eurogrupy, załączonego do TUE i TFUE ${ }^{79}$.

24 listopada 2015 r. Komisja Europejska zgłosiła nowy wniosek ustawodawczy w sprawie utworzenia Europejskiego Systemu Gwarantowania Depozytów. Był to wniosek nowelizujący wspomniane wyżej rozporządzenie Parlamentu Europejskiego i Rady Unii Europejskiej z 15 lipca 2014 r. w sprawie ustanowienia Jednolitego Mechanizmu Restrukturyzacji i Uporządkowanej Likwidacji oraz Jednolitego Funduszu Restrukturyzacji i Uporządkowanej Likwidacji ${ }^{80}$. Jak wspomniano wyżej, zarówno rozporządzenie Parlamentu Europejskiejgo i Rady z dnia 15 lipca 2014 r. ustanawiające Jednolity Mechanizm Restrukturyzacji i Uporządkowanej Likwidacji oraz Jednolity Fundusz Restrukturyzacji i Uporządkowanej Likwidacji, jak i dyrektywa Parlamentu Europejskiego i Rady z dnia 15 maja 2014 r. ustanawiająca ramy na potrzeby prowadzenia działań naprawczych oraz restrukturyzacji i uporządkowanej likwidacji zawierały przepisy umożliwiające wykorzystanie środków pochodzących z systemów gwarantowania depozytów na rzecz restrukturyzacji i uporządkowanej likwidacji instytucji kredytowych, w tym banków. Także w tym sensie ustanowienie unijnego systemu gwarantowania depozytów byłoby zatem logicznym, kolejnym krokiem w kierunku zakończenia procesu konstytuowania Unii Bankowej. Mając na uwadze, że przepisy

79 Komisja Europejska, Wniosek. Decyzja Rady określająca środki na rzecz stopniowego ustanowienia jednolitej reprezentacji strefy euro w Międzynarodowym Funduszu Walutowym, Bruksela, 21 X 2015 r., $\operatorname{COM}(2015) 603$ wersja ostateczna, s. 1-10. Już w komunikacie poprzedzającym analizowany wniosek Komisja Europejska zastrzegła sobie możliwość przedłożenia kolejnych projektów ustawodawczych mających na celu wzmocnienie zewnętrznej reprezentacji strefy euro również na innych forach międzynarodowych. Por. Komisja Europejska, Komunikat Komisji do Parlamentu Europejskiego, Rady oraz Europejskiego Banku Centralnego „Plan dziatania na rzecz bardziej spójnej zewnętrznej reprezentacji strefy euro", s. 1-12.

80 Skoro utworzenie EDIS wymagało zmiany tego rozporządzenia, potwierdzało to tylko wspomnianą wyżej opinię, że mechanizmy finansowania w Unii Bankowej, czyli SRF, EDIS i CB, były ze sobą bardzo ściśle powiązane. Por. Komisja Europejska, Wniosek. Rozporządzenie Parlamentu Europejskiego i Rady zmieniajace rozporzadzenie (UE) nr 806/2014 w celu ustanowienia europejskiego systemu gwarantowania depozytów, Strasburg, 24 XI 2015 r., COM(2015) 586 wersja ostateczna, s. 1-82. Wnioskowi temu towarzyszył komunikat Komisji Europejskiej przewidujący wprowadzenie środków pozwalających na dalsze ograniczenie utrzymującego się ryzyka dla systemu bankowego, równolegle do prac nad ustanowieniem EDIS. Por. Komisja Europejska, Komunikat Komisji do Parlamentu Europejskiego, Rady, Europejskiego Banku Centralnego, Europejskiego Komitetu Ekonomiczno-Spotecznego oraz Komitetu Regionów „Droga do utworzenia unii bankowej”, Strasburg, 24 XI 2015 r., COM(2015) 587 wersja ostateczna, s. 1-13. 
dotyczące ustanowienia i funkcjonowania EDIS winny być bezpośrednio stosowane w państwach członkowskich oraz w celu uniknięcia ich rozbieżnych wykładni w poszczególnych państwach, Komisja Europejska zaproponowała rozporządzenie jako właściwy instrument prawny ${ }^{81}$.

W skład EDIS miały wchodzić tylko państwa uczestniczące w Unii Bankowej. Powinien on się opierać na istniejącym już mechanizmie harmonizacji krajowych systemów gwarantowania depozytów, zarządzanych zgodnie z dyrektywą DGSD, ale docelowo miał także doprowadzić do ich unifikacji. Winien on być stopniowo przekształcany z systemu reasekuracji do w pełni uwspólnionego systemu koasekuracji. Proces budowy Europejskiego Systemu Gwarantowania Depozytów miałby obejmować trzy etapy: po pierwsze, okres reasekuracji (2017-2020), podczas którego EDIS dostarczałby dodatkowych funduszy dla krajowych systemów gwarantowania depozytów, gdyby znalazły się one w sytuacji wymagającej wypłaty środków gwarantowanych lub finansowania przymusowej restrukturyzacji; po drugie, fazę koasekuracji (2020-2024), w czasie której dzięki EDIS doszłoby do stopniowego zwiększenia poziomu uwspólnienia ryzyka między krajowymi systemami gwarancji depozytów; po trzecie, pełne ubezpieczenie depozytów przez EDIS (od 2024 r.) $)^{82}$. Uprawnienia decyzyjne, nadzorcze i wykonawcze posiadałaby w ramach EDIS Jednolita Rada ds. Restrukturyzacji i Uporządkowanej Likwidacji oraz Gwarantowania Depozytów, powstała z przekształcenia dotychczasowej Jednolitej Rady ds. Restrukturyzacji i Uporządkowanej Likwidacji, należącej do drugiego filaru Unii Bankowej ${ }^{83}$. W celu realizacji zadań EDIS projekt zakładał utworzenie Funduszu Ubezpieczenia Depozytów (Deposit Insurance Fund - DIF), finansowanego ze składek ex ante wpłacanych przez banki bezpośrednio Jednolitej Radzie oraz obliczanych i fakturowanych przez uczestniczące systemy gwarantowania depozytów ${ }^{84}$.

Ocena działań Komisji Europejskiej w pierwszym okresie realizacji reformy wypada niezbyt imponująco. W połowie 2016 r. trzy spośród czterech analizowanych wyżej wniosków ustawodawczych nadal znajdowaly się w trakcie procedur legislacyjnych. Były to: projekt rozporządzenia Parlamentu Europejskiego i Rady Unii Europejskiej zmieniającego rozporządzenie (UE) nr 806/2014 w celu ustanowienia europejskiego systemu gwarantowania depozytów; projekt decyzji Rady Unii Europejskiej

81 Komisja Europejska, Wniosek. Rozporzadzenie Parlamentu Europejskiego i Rady zmieniajace rozporzadzenie (UE) nr 806/2014..., s. 6-7.

82 W okresie reasekuracji mial powstać system reasekuracji, który $w$ pewnym stopniu zapewniałby finansowanie oraz pokrywałby część strat krajowych systemów gwarantowania depozytów. W fazie koasekuracji utworzono by system koasekuracji, który $w$ większym stopniu zapewniałby finansowanie oraz pokrywałby straty systemów krajowych. W 2024 r. stworzony zostałby natomiast system pełnego zabezpieczenia, który zapewniałby finansowanie oraz pokrywałby w 100\% straty krajowych systemów. W odróżnieniu od okresu reasekuracji w fazie koasekuracji krajowe systemy gwarancji depozytów nie byłyby zobowiązane do wyczerpania środków własnych przed uzyskaniem wsparcia finansowego ze strony EDIS. W obydwu przypadkach warunkiem byłaby konieczność pokrycia przez krajowe systemy wypłat na rzecz depozytariuszy lub finansowania przymusowej restrukturyzacji. Por. tamże, s. 9, 32-33.

83 Tamże, s. 24.

84 Tamże, s. 9, 18. 
określającej środki na rzecz stopniowego ustanowienia jednolitej reprezentacji strefy euro w MFW, a także projekt zalecenia Rady Unii Europejskiej w sprawie ustanowienia w strefie euro krajowych rad ds. konkurencyjności. Natomiast decyzja Komisji Europejskiej w sprawie ustanowienia niezależnej Europejskiej Rady Budżetowej weszła w życie 1 listopada $2015 \mathrm{r}^{85}$

\section{UWAGI KOŃCOWE}

Obserwując dotychczasową dynamikę reformy ustrojowej strefy euro, zaprojektowanej w grudniu 2012 r., odnosi się wrażenie, że nie zrodziła się ona pod szczęśliwą gwiazdą. W 2014 r. we wschodnim oraz w południowym sąsiedztwie Unii Europejskiej wybuchly dwa, najpoważniejsze od zakończenia zimnej wojny, kryzysy geopolityczne, spowodowane wojną na Ukrainie oraz powstaniem tzw. Państwa Islamskiego. Jednym z rezultatów tych ostatnich wydarzeń był kryzys migracyjny Unii Europejskiej, który w 2015 r. zagroził podstawom jej egzystencji. W tym samym roku, mimo wielkich nakładów finansowych na walkę z kryzysem zadłużeniowym, Grecja stanęła w obliczu gospodarczego bankructwa. W połowie 2016 r. UE wstrząsnęły z kolei wydarzenia związane z referendum w Wielkiej Brytanii, podczas którego społeczeństwo tego państwa większością 51,89\% głosów opowiedziało się za wystąpieniem z Unii Europejskiej.

Mimo istotnych postępów w procesie tworzenia rzeczywistej Unii Gospodarczej i Walutowej, w szczególności w zakresie konstytuowania Unii Bankowej, nadal wiele celów reformy ustrojowej strefy euro nie zostało zrealizowanych. W latach 2013-2015 udało się ustanowić dwa spośród trzech filarów Unii Bankowej. Nie dysponuje ona zatem w dalszym ciągu pełną strukturą organizacyjną. Również dynamika prac nad pozostałymi zmianami ustrojowymi przebiegała z opóźnieniem w stosunku do harmonogramu przyjętego przez Radę Europejską w grudniu 2012 r. W toku były bowiem nadal działania na rzecz utworzenia Unii Fiskalnej, zaś wskutek sprzeciwu niektórych państw członkowskich nie rozpoczęto prac, ani nawet nie podjęto decyzji o ustanowieniu wspólnego budżetu strefy euro, czyli najbardziej kontrowersyjnego celu całej reformy. Nie udało się również utworzyć mechanizmu koordynacji i konwergencji oraz realizacji polityk strukturalnych państw strefy euro w oparciu o umowy reformatorskie. Ponadto w dalszym ciągu utrzymywały się w Unii Europejskiej takie symptomy kryzysu, jak chociażby znaczna rozbieżność w zakresie wyników gospodarczych w całej strefie euro, prawie 18-milionowe bezrobocie oraz zagrożenie wykluczeniem społecznym w wielu państwach członkowskich. W tej sytuacji w czerwcu 2015 r. ogłoszono raport pięciu przewodniczących, który szedł o wiele dalej aniżeli raport Van Rompuya sprzed dwóch i pół roku. O ile ten ostatni nadawał wyraźny kierunek reformie ustrojowej strefy euro i całej UGiW, o tyle raport pięciu przewodniczących przedstawiał już bardzo konkretne cele, instrumenty, metody oraz precyzyjny harmonogram realizacji reformy.

85 Decyzja Komisji (UE) 2015/1937 z dnia 21 października 2015 r. ustanawiająca niezależna doradcza Europejska Radę Budżetowa, Dz.U. UE L, 2015, nr 282, s. 37-40. 
W jej wyniku miałoby dojść do ustanowienia w UGiW Unii Gospodarczej, Unii Finansowej, Unii Fiskalnej oraz zrębów Unii Politycznej.

Dlatego też podstawowym problemem w procesie realizacji reformy strefy euro wydaje się zakres jej zmian ustrojowych oraz umiejętność ich pogodzenia z wymogami integralności całej Unii Europejskiej. Choć ustanowienie Unii Gospodarczej, Unii Finansowej oraz Unii Fiskalnej wydaje się niezbędne dla ostatecznego przezwyciężenia kryzysu zadłużeniowego oraz usprawnienia funkcjonowania i wzmocnienia stabilności strefy euro, to proces ten będzie niezwykle trudny do przeprowadzenia z powodu oporu niektórych państw członkowskich, zwłaszcza krajów nienależących do strefy. W tej chwili trudno przewidzieć, czy utworzenie rzeczywistej Unii Gospodarczej i Walutowej będzie skutkować fragmentaryzacją Unii Europejskiej („Europa dwóch prędkości” lub nawet „Europa wielu prędkości”), czy też raczej zachęci oponentów do akcesji do zreformowanej strefy euro. Teoretycznie rzecz biorąc, skala ryzyka fragmentaryzacji Unii Europejskiej będzie zależała od zakresu podjętych reform. Najmniejsze ryzyko fragmentaryzacji może wystąpić w przypadku ustanowienia Unii Bankowej, większe w razie utworzenia Unii Bankowej, Unii Fiskalnej i Unii Gospodarczej, zaś największe w sytuacji, gdyby w ramach Unii Fiskalnej doszło do utworzenia odrębnego budżetu dla strefy euro, a także ustanowienia w strefie zrębów Unii Politycznej.

\section{BIBLIOGRAFIA}

\section{I. Źródła}

Decyzja Komisji (UE) 2015/1937 z dnia 21 października 2015 r. ustanawiająca niezależna doradcza Europejska Radę Budzetowa, Dz.U. UE L, 2015, nr 282.

Dyrektywa Parlamentu Europejskiego i Rady 2014/49/UE z dnia 16 kwietnia 2014 r. w sprawie systemów gwarancji depozytów, Dz.U. UE L, 2014, nr 173.

Dyrektywa Parlamentu Europejskiego i Rady 2014/59/UE z dnia 15 maja 2014 r. ustanawiajaca ramy na potrzeby prowadzenia dziatan naprawczych oraz restrukturyzacji i uporzadkowanej likwidacji w odniesieniu do instytucji kredytowych i firm inwestycyjnych oraz zmieniajaca dyrektywe Rady 82/891/EWG i dyrektywy Parlamentu Europejskiego i Rady 2001/24/WE, 2002/47/WE, 2004/25/WE, 2005/56/WE, 2007/36/WE, 2011/35/UE, 2012/30/UE i 2013/36/EU oraz rozporzadzenia Parlamentu Europejskiego i Rady (UE) nr 1093/2010 $i$ (UE) nr 648/2012, Dz.U. UE L, 2014, nr 173.

Komisja Europejska, Dokończenie budowy europejskiej Unii Gospodarczej i Walutowej. Sprawozdanie opracowane przez: Jeana-Claudéa Junckera w ścistej wspótpracy z Donaldem Tuskiem, Jeroenem Dijsselbloemem, Mario Draghim i Martinem Schulzem, Bruksela, 22 VI 2015 r.

Komisja Europejska, Komunikat Komisji do Parlamentu Europejskiego, Rady, Europejskiego Banku Centralnego, Europejskiego Komitetu Ekonomiczno-Spotecznego oraz Komitetu Regionów „Droga do utworzenia unii bankowej", Strasburg, 24 XI 2015 r., COM(2015) 587 wersja ostateczna.

Komisja Europejska, Komunikat Komisji do Parlamentu Europejskiego, Rady, Europejskiego Komitetu Ekonomiczno-Spotecznego i Komitetu Regionów „Plan dziatania na rzecz tworzenia unii rynków kapitatowych", Bruksela, 30 IX 2015 r., COM(2015) 468 wersja ostateczna. 
Komisja Europejska, Komunikat Komisji do Parlamentu Europejskiego, Rady oraz Europejskiego Banku Centralnego w sprawie dziatań na rzecz dokończenia budowy unii gospodarczej i walutowej, Bruksela, 21 X 2015 r., $\operatorname{COM(2015)~} 600$ wersja ostateczna.

Komisja Europejska, Komunikat Komisji do Parlamentu Europejskiego, Rady i Europejskiego Banku Centralnego „Plan dziatania na rzecz bardziej spójnej zewnętrznej reprezentacji strefy euro na forach międzynarodowych”, Bruksela, 21 X 2015 r., COM(2015) 602 wersja ostateczna.

Komisja Europejska, Komunikat prasowy. Plan dziatania na rzecz pogtębionej i rzeczywistej Unii Gospodarczej i Walutowej (UGW): poczatek europejskiej debaty, Bruksela, 28 XI 2012 r., IP/12/1272.

Komisja Europejska, Komunikat prasowy. W sprawozdaniu czterech przewodniczacych i prezesa EBC określono plan wzmocnienia europejskiej unii gospodarczej i walutowej od 1 lipca 2015 r., Bruksela, 22 VI 2015 r.

Komisja Europejska, Notatka prasowa. Unia Bankowa: przywracamy stabilność finansowa w strefie euro, Bruksela, 15 IV $2014 \mathrm{r}$.

Komisja Europejska, Wniosek. Decyzja Komisji (UE) 2015/1937 z dnia 21 października 2015 r. ustanawiająca niezależna doradczą Europejskq Radę Budżetową, Dz.U. UE L, 2015, nr 282.

Komisja Europejska, Wniosek. Decyzja Rady określająca środki na rzecz stopniowego ustanowienia jednolitej reprezentacji strefy euro w Międzynarodowym Funduszu Walutowym, Bruksela, 21 X 2015 r., $\operatorname{COM(2015)~} 603$ wersja ostateczna.

Komisja Europejska, Wniosek. Rozporzadzenie Parlamentu Europejskiego i Rady zmieniajace rozporzadzenie (UE) $n r$ 806/2014 w celu ustanowienia europejskiego systemu gwarantowania depozytów, Strasburg, 24 XI 2015 r., COM(2015) 586 wersja ostateczna.

Komisja Europejska, Wniosek. Zalecenie Rady w sprawie ustanowienia w strefie euro krajowych rad ds. konkurencyjności, Bruksela, 21 X 2015 r., COM(2015) 601 wersja ostateczna.

Komisja Europejska. Dyrekcja Generalna Sprawy Gospodarcze i Finansowe, Przysztośc UGW. Plan dziatania na przysztość, [online] http://ec.europa.eu/economy_finance/explained/ economic_and_monetary_union/the_future_of_emu.

Ministerstwo Gospodarki RP, Semestr europejski. Okres oceny i koordynacji polityki gospodarczej w UE, Warszawa 2014.

Posiedzenie Rady Europejskiej w dniach 13-14 grudnia 2012 r. Konkluzje, Bruksela, 14 XII 2012 r., EUCO 205/12.

Posiedzenie Rady Europejskiej w dniach 14-15 marca 2013 r. Konkluzje, Bruksela, 14 III 2013 r., EUCO 23/13.

Posiedzenie Rady Europejskiej w dniach 17-18 grudnia 2015 r. Konkluzje, Bruksela, 18 XI 2015 r., EUCO 28/15.

Posiedzenie Rady Europejskiej w dniach 20-21 marca 2014 r. Konkluzje, Bruksela, 21 III 2014 r., EUCO 7/1/14, REV 1.

Posiedzenie Rady Europejskiej w dniach 25-26 czerwca 2015 r. Konkluzje, Bruksela, 26 VI 2015 r., EUCO 22/15.

Posiedzenie Rady Europejskiej w dniach 27-28 czerwca 2013 r. Konkluzje, Bruksela, 28 VI 2013 r., EUCO 104/2/13, REV 2.

Posiedzenie Rady Europejskiej w dniu 15 października 2015 r. Konkluzje, Bruksela, 16 X 2015 r., EUCO 26/15. 
Posiedzenie Rady Europejskiej w dniu 28 czerwca 2016 r. Konkluzje, Bruksela, 28 VI 2016 r., EUCO 26/16.

Rada Europejska, Sprawozdanie przewodniczacego Rady Europejskiej Hermana Van Rompuya „W kierunku faktycznej Unii Gospodarczej i Walutowej”. Komunikat prasowy, Bruksela, 26 VI 2012 r., EUCO 120/12.

Rada Europejska. Przewodniczący, W kierunku faktycznej Unii Gospodarczej i Walutowej. Sprawozdanie okresowe, Bruksela, 12 X 2012 r.

Rada Europejska. Przewodniczący, W kierunku faktycznej Unii Gospodarczej i Walutowej. [Sprawozdanie końcowe], Bruksela, 5 XII 2012 r.

Rada Unii Europejskiej. Sekretariat Generalny, Jak wyglada europejski semestr?, [online] http:// www. consilium. europa.eu/pl/ policies/european-semester/.

Rozporzadzenie Parlamentu Europejskiego i Rady (UE) nr 806/2014 z dnia 15 lipca 2014 r. ustanawiajace jednolite zasady i jednolita procedure restrukturyzacji i uporzadkowanej likwidacji instytucji kredytowych $i$ niektórych firm inwestycyjnych $w$ ramach jednolitego mechanizmu restrukturyzacji i uporzadkowanej likwidacji oraz jednolitego funduszu restrukturyzacji i uporządkowanej likwidacji oraz zmieniajace rozporządzenie (UE) nr 1093/2010, Dz.U. UE L, 2014, nr 225.

Rozporządzenie Rady (UE) nr 1024/2013 z dnia 15 października 2013 r.powierzajace Europejskiemu Bankowi Centralnemu szczególne zadania w odniesieniu do polityki zwiąanej z nadzorem ostrożnościowym nad instytucjami kredytowymi, Dz.U. UE L, 2013, nr 287.

Semestr europejski. Przebieg cyklu koordynacji na poziomie Unii i Polski (2011-2016) (stan prawny na 30 listopada 2015), Ośrodek Informacji i Dokumentacji Europejskiej. Biblioteka Sejmowa, [online] https://oide.sejm.gov.pl/.

Traktat z Lizbony zmieniajacy Traktat o Unii Europejskiej i Traktat ustanawiajacy Wspólnote Europejska, podpisany w Lizbonie 13 grudnia 2007 r. (teksty skonsolidowane), Dz.U. UE C, 2008, nr 115.

Umowa o przekazywaniu i uwspólnianiu sktadek na rzecz Jednolitego Funduszu Restrukturyzacji i Uporzadkowanej Likwidacji, Bruksela, 21 V 2014 r., EU/SRF.

\section{Opracowania}

Banking Union for Europe. Risks and Challenges, red. T. Beck, London 2012.

Beck T., Peydró J.-L., Five Years of Crisis (Resolution) - Some Lessons, [w:] Eurozone Crisis. A Consensus View of the Causes and a Few Possible Solutions, red. R. Baldwin, F. Giavazzi, London 2015.

De Grauwe P., Desing Failures of the Eurozone, [w:] Eurozone Crisis. A Consensus View of the Causes and a Few Possible Solutions, red. R. Baldwin, F. Giavazzi, London 2015.

Europejski Bank Centralny - rozpoczęcie nadzorowania banków strefy euro przez EBC, „Przegląd Spraw Europejskich” 2014, nr 11.

Eurozone Crisis. A Consensus View of the Causes and a Few Possible Solutions, red. R. Baldwin, F. Giavazzi, London 2015.

Frankel J., Causes of Eurozone Crises, [w:] Eurozone Crisis. A Consensus View of the Causes and a Few Possible Solutions, red. R. Baldwin, F. Giavazzi, London 2015.

Götz M., Kryzys i przysztość strefy euro, Warszawa 2012. 
Gruszczyński M., Kryzysy walutowe, bankowe i zadtużeniowe w gospodarce światowej, Warszawa 2013.

Jurkowska-Zeidler A., Fundamentalne zmiany regulacji i nadzoru jednolitego rynku finansowego Unii Europejskiej w ramach Unii Bankowej, „Gdańskie Studia Prawnicze” 2015, t. 33.

Koleśnik J., Europejska unia bankowa - nowy wymiar ryzyka systemowego, „Problemy Zarządzania" 2013, t. 11, nr 2.

Komisja Europejska - drugi filar Unii Bankowej w petni operacyjny, „Przegląd Spraw Europejskich” 2016, nr 1.

Komisja Europejska - początek prac nad projektem unii rynków kapitatowych, „Przegląd Spraw Europejskich" 2015, nr 1.

Komisja Europejska - Publikacja „Planu dziatania na rzecz tworzenia unii rynków kapitalowych”, „Przegląd Spraw Europejskich” 2015, nr 8/9.

Kunstein T., Wessels W., Die Europäische Union in der Währungskrise. Eckdaten und Schlüsselentscheidungen, „Integration” 2011, Vol. 34, nr 4, [online] http://dx.doi.org/10.5771/ 0720-5120-2011-4-308.

Nosiadek G., Unia bankowa krajów Unii Europejskiej, „Myśl Ekonomiczna i Polityczna” 2014, nr 3.

Patynowska J., Horyzonty Bankowości 2015: Trzy filary stabilności, „Miesięcznik Finansowy Bank" III 2015.

Pietrzykowski M., Polska na drodze do reformowanej strefy euro, Poznań 2014.

Rada Europejska - oświadczenie przywódców państw strefy euro, „Przegląd Spraw Europejskich” 2014, nr 10.

Rada Unii Europejskiej - Posiedzenie Rady Ecofin 25 maja 2016 r. Postępy we wdrażaniu Unii Bankowej, „Przegląd Spraw Europejskich” 2016, nr 5.

Rada Unii Europejskiej - wdrażanie Unii Bankowej, „Przegląd Spraw Europejskich” 2016, nr 2.

Schoenmaker D., Banking Union: Where We're Going Wrong, [w:] Banking Union for Europe. Risks and Challenges, red. T. Beck, London 2012.

Unia bankowa, red. M. Zaleska, Warszawa 2013, Studia Finansów i Bankowości.

Waliszewski K., Koncepcja unii bankowej - szanse i zagrożenia dla sektora banków komercyjnych w Polsce, [w:] Unia bankowa, red. M. Zaleska, Warszawa 2013.

Waliszewski K., Unia bankowa i unia rynków kapitatowych - analiza porównawcza europejskich projektów integracyjnych w obszarze finansowym, „Nauki o Finansach. Financial Sciences” 2015, nr 2, [online] http://dx.doi.org/10.15611/nof.2015.2.07.

Węc J.J., The European Union Debate on the Second Institutional Reform (2011-2012), „Przegląd Zachodni" 2014, nr 1.

Węc J.J., Die politische Debatte zur zweiten Systemreform der Europäischen Union in Deutschland (2011-2012), „Zeitschrift des Verbandes Polnischer Germanisten” 2014, nr 2.

Węc J.J., Pierwsza polska prezydencja w Unii Europejskiej. Uwarunkowania - procesy decyzyjne osiagnięcia i niepowodzenia, Kraków 2012, Societas, 44.

Węc J.J., Proces konstytuowania Unii Bankowej. Geneza, podstawy prawne, cele i zasady dziatania, „Rocznik Integracji Europejskiej” 2014, nr 8, [online] http://dx.doi.org/10.14746/ rie.2014.8.3. 
Węc J.J., Relacje polsko-niemieckie w Unii Europejskiej i NATO na poczatku XXI w. Próba bilansu, „Prace Komisji Środkowoeuropejskiej PAU” 2015, t. 23.

Zaleska M., Unia bankowa - koncepcja i wyzwania, [w:] Unia bankowa, red. taż, Warszawa 2013.

Zielińska K., Drogi do unii bankowej - reformy systemu regulacji systemu bankowego, „Ekonomia Międzynarodowa" 2013, z. 4 .

Prof. dr hab. Janusz Józef WĘC - profesor zwyczajny nauk humanistycznych w zakresie historii powszechnej najnowszej i stosunków międzynarodowych. Kierownik Katedry Studiów nad Procesami Integracyjnymi w Instytucie Nauk Politycznych i Stosunków Międzynarodowych Uniwersytetu Jagiellońskiego w Krakowie. Autor ponad 200 publikacji naukowych wydanych w kraju i za granica, w tym 18 monografii i syntez, na temat ustroju Wspólnot Europejskich i Unii Europejskiej, integracji europejskiej i pozaeuropejskiej, stosunków polsko-niemieckich, najnowszej historii Niemiec, a także niemieckiego systemu politycznego. Ostatnio wydane monografie: Traktat Lizboński. Polityczne aspekty reformy ustrojowej Unii Europejskiej w latach 2007-2015, Kraków 2016; Pierwsza polska prezydencja w Unii Europejskiej. Uwarunkowania - procesy decyzyjneosiagnięcia i niepowodzenia, Kraków 2012; Spór o ksztatt ustrojowy Wspólnot Europejskich i Unii Europejskiej w latach 1950-2010. Między idea ponadnarodowości a wspótpraca międzyrządowa. Analiza politologiczna, Kraków 2012; Sozialliberale Ostpolitik: Die FDP und der Warschauer Vertrag. Die Haltung der FDP gegenüber den Verhandlungen mit Polen über den Warschauer Vertrag vom 7. Dezember 1970, Potsdam 2011. 